Who is a Refugee?: Twenty-Five years of Domestic Implementation and Judicial Interpretation of the 1969 OAU and 1951 UN Refugee Conventions in Post-Apartheid South Africa

Tiyanjana Maluwa

Anton Katz SC

Follow this and additional works at: https://elibrary.law.psu.edu/fac_works

Part of the Comparative and Foreign Law Commons 


\title{
Who is a Refugee?: Twenty-Five years of Domestic Implementation and Judicial Interpretation of the 1969 OAU and 1951 UN Refugee Conventions in Post-Apartheid South Africa
}

\author{
Tiyanjana MaluWA* AND ANTON KaTz SC** \\ TABLE OF CONTENTS
}

\section{INTRODUCTION}

I. The Oau Refugee Convention: Expansion of the Un Refugee Convention Definition and Other Aspects
A. Expanding the Definition of a Refugee
B. Reaffirming the Principle of Non-refoulement
C. Exploring the Right to Asylum
D. Explaining the Other Aspects: Burden-Sharing, Temporary Protection, and Voluntary Repatriation

II. Refugee Status Determination Procedures under South African Law

A. Refugee Status Determination Procedure, 1994 to 2000

B. Refugee Status Determination Procedure under the Refugees Act, 1998

(i) Asylum Seekers: "Section 22 Permit"

(ii) Decisions on Asylum Applications

C. Objectives and Other Aspects of the Refugees Act, 1998

1. Non-refoulement and Access to South African Territory

2. Treatment of Asylum Seekers and Refugees: Detention, Exclusion and Cessation
(i) Detention of Failed Asylum Seekers
(ii) Exclusion from Refugee Status
(iii) Cessation of Refugee Status

III. Judicial Interpretation of the Oau Refugee Convention Definition
A. Definition of a Refugee under South African Law
B. Burden, Standard of Proof, and Consequences of Refugee Status

* H. Laddie Montague Chair in Law \& Professor of Law and International Affairs,
Pennsylvania State Univeristy-Univeristy Park, PA.
**Advocate \& Senior Counsel; Member of the Cape Bar, South Africa \& New York Bar.

Indiana Journal of Global Legal Studies Vol. 27 \#2 (Spring 2020)

(C) Indiana University Maurer School of Law 
C. Interpretation of the Expanded OAU Refugee Convention Definition

1. Events Seriously Disturbing Public Order

2. Political Opinion

3. Membership of a Particular Social Group

CONCLUSION

ABSTRACT

As a party to the UN Refugee Convention and the OAU Refugee Convention, South Africa is obligated to apply international refugee law when addressing the protection needs of asylum seekers in the country. The Refugees Act, 1998 encapsulates the cardinal principles of the two conventions. This essay discusses how government officials and judges have interpreted and applied these principles in asylum application cases. These cases demonstrate that officials are either not always fully conversant with the legal obligations, incumbent upon the government, arising from both international law and domestic law or purposefully ignore them. For the most part, officials tend to treat asylum seekers presumptively as economic migrants rather than bona fide refugees entitled to proper scrutiny under the criteria set out in the refugee conventions. This approach has resulted in gaps between legal protection and practical protection of refugees in South Africa and has on several occasions been criticized and rejected by courts, including the Constitutional Court of South Africa.

\section{INTRODUCTION}

South Africa shares the distinction with only a few other countries of being, at various times in its history, either a refugee-sending country (country of origin) or a refugee-receiving country (host country). The ebb and flow of refugees into and out of South Africa has varied markedly over the years, and the refugee situation has been the subject of scholarly debate and discussion. ${ }^{1}$ On the one hand, South Africa has hosted asylum seekers and refugees throughout its modern history, particularly since attaining the status of a fully independent state in the early twentieth century. ${ }^{2}$ On the other hand, the three decades of the

1. For this essay, we partly draw on some material which appears in our co-authored chapter, Anton Katz \& Tiyanjana Maluwa, Refugees and Stateless Persons, in DUGARD's INTERNATIONAL LAW: A SOUTH AFRICAN PERSPECTIVE 502-38 (5th ed. 2019) (discussing the legal regime for refugee protection in South Africa).

2. The earliest accounts of refugee flight into precolonial South Africa can be traced to the early decades of European settlement of the Cape of Good Hope in the latter half of the seventeenth century, with the arrival of French Huguenots in 1688. Two and half 
anti-apartheid and national liberation struggle from the early 1960s to the early 1990s forced significant numbers of South Africans to flee the country and seek refuge in other African countries and elsewhere. ${ }^{3}$ However, since the end of apartheid, South Africa has largely become a host country to refugees and asylum seekers, mostly from other African countries. These include Mozambique and Zimbabwe, on the border of South Africa, and more distant countries such as the Democratic Republic of the Congo and Burundi, in Central Africa; and Eritrea and Somalia, in the Horn of Africa. During the five-year period from 2006 to 2011, for example, South Africa reportedly received the highest number of new asylum applications per year of any country in the world. ${ }^{4}$ Although the number of asylum seekers has declined progressively over the decade from 2008 to 2018, South Africa remains one of the world's major destinations for new asylum seekers. Yet it is no longer in the top ten countries hosting asylum seekers. ${ }^{5}$ By mid-2018, the number of

centuries later, subsequent refugees included Jews escaping from Hitler's Germany and the Holocaust in Europe from the early 1930s onwards. See generally PIETER COERTZEN, THE HUGUENOTS OF SOUTH AFRICA 1688.1988 (1988) (discussing the arrival, incorporation, and contribution of this group of settlers). See also Mark Boucher, Huguenot Refugees: Some Links Between the Cape, France and England in the Early Eighteenth Century, 20 HISTORIA 55, 55 (1975).

3. The number of South Africans who went into exile because of apartheid from the early 1960s has been estimated at between 40,000 and 60,000. See Zosa O. De Sas Kropiwnicki, The Meeting of Myths and Realities: The "Homecoming" of Second-Generation Exiles in Post-Apartheid South Africa, 30 REFUGE 79, 79 (2014). These estimates do not include South Africans who migrated and settled in other countries without seeking or being granted formal refugee status in those countries or being designated as such by the Office of the United Nations High Commissioner for Refugees (UNHCR). According to the UNHCR, by mid-2018, the number of refugees and asylum-seekers of South African origin in other countries were only 489 and 145, respectively. See U.N. REFUGEE AGENCY, GLOBAL TRENDS: FORCED DISPLACEMENT IN 2018, at 73 (2019), http://www.unhcr.org/globaltrends2018/.

4. U.N. REFugeE AgenCY, Global TREnds 2012: DisplaceMENT - THE NEW 21ST CENTURY CHALLENGE 26 (2013), http://www.unhcr.org/statistics/country/51bacb0f9/unhcrglobal-trends-2012.html.

5. See S. Afr. Dep't of Home Affairs, White Paper on International Migration, at 59-63 (July 2017), http://www.dha.gov.za/WhitePaperonInternationalMigration-20170602.pdf. See also U.N. REFUGEE AGENCY, supra note 3, at 42. Some researchers and nongovernmental organizations working on refugee issues have questioned the methodology used by the South African Department of Home Affairs and the UNHCR for compiling their statistics over the years. See generally Richard Stupart, Is South Africa Home to More Than a Million Asylum Seekers? The Numbers Don't Add up, AFR. CHECK, http://africacheck.org/reports/south-africa-home-million-refugees-numbers-dont-add-up/ (last updated Feb, 8, 2018) (challenging the claim in the UNHCR's report for 2015 that South Africa was home to more than a million asylum-seekers and had the highest number of unresolved asylum cases in the world; and arguing that the combined figure of more than 3.2 million refugees and asylum-seekers was based on a flawed reading of the 
refugees and asylum seekers of concern to the United Nations High Commissioner for Refugees (UNHCR) in South Africa stood at 89,285 and 184,203 , respectively. ${ }^{6}$ Despite this drop in numbers, the refugees and asylum seekers question remains a challenge in South Africa, in part because it is often conflated with the larger, and politically controversial issue, of illegal immigration. ${ }^{7}$

The year 2019 marked the fiftieth anniversary of the adoption of the Organization of African Union Convention Governing the Specific Aspects of Refugee Problems in Africa of 1969 (OAU Refugee Convention), ${ }^{8}$ and the twenty-fifth anniversary of the emergence of postapartheid South Africa. ${ }^{9}$ The year 2021 will mark the seventieth anniversary of the adoption of the United Nations Convention Relating to the Status of Refugees of 1951 (UN Refugee Convention). ${ }^{10}$ These anniversaries present an opportune moment to reflect upon the relevance and impact of the two conventions in South Africa, especially as they relate to the treatment of asylum seekers and the determination of refugee status. More attention is given to the OAU Refugee Convention in this respect, not only because it establishes Africa's regional refugee protection regime, but also because its adoption was partly motivated by the need to address the situation of refugees fleeing apartheid and minority rule in South Africa. As Marina Sharpe has observed, "[the] attention paid by the OAU to refugees was very much a

available data and the continued counting of persons who had moved out of the asylum system).

6. U.N. REFUGEE AGENCY, supra note 3 , at 67.

7. See generally Oluwaseun Tella, Understanding Xenophobia in South Africa: The Individual, the State and the International System, 8 INSIGHT ON AFR. 142 (2016) (analyzing the recurrent anti-immigrant attitudes and attacks in South Africa).

8. Convention Governing the Specific Aspects of Refugee Problems in Africa, Sept. 10, 1969, 1001 U.N.T.S. 45 [hereinafter OAU Refugee Convention]. South Africa acceded to the OAU Refugee Convention on Dec. 15, 1995. There is a tendency among some commentators nowadays to refer to it as the "AU Refugee Convention", which is wrong as it misrepresents the official title of the treaty. See, e.g., Cristiano D'Orsi, The $A U$ Convention on Refugees and the Concept of Asylum, 3 PACE INT'L L. REV. 220, 220 (2012).

9. Apartheid, a system of institutionalized racial segregation, came to an end in the early $1990 \mathrm{~s}$ in a series of steps that led to the formation of a non-racial, democratic government. Formally, post-apartheid South Africa came into existence with the inauguration of Nelson Mandela as president on May 10, 1994, following the first democratic election held on Apr. 27, 1994. Apartheid South Africa was not a party to the UN Refugee Convention and, as a non-member of the OAU, it could not join the OAU Refugee Convention. It also had no domestic legislation on refugees.

10. Convention Relating to the Status of Refugees, July 28, 1951, 189 U.N.T.S. 137 [hereinafter UN Refugee Convention]. South Africa acceded to the UN Refugee Convention on Jan. 12, 1996. On the same day, it also acceded to the Protocol Relating to the Status of Refugees of 1967, Jan. 31, 1967, 606 U.N.T.S. 267 [hereinafter Refugee Protocol]. 
product of its concern with liberating Africa from colonialism and minority rule."11

Refugees in South Africa are governed by a legal regime drawn from international law, on the one hand, and South African municipal law, on the other. ${ }^{12}$ The former regime - international law-is based on universal and regional conventions, rules of customary international law, general principles of law, and ever-evolving standards in the practice of states and international organizations, in particular the Office of the UNHCR. ${ }^{13}$ The latter regime-South African lawcomprises the Constitution of the Republic of South Africa, 1996 (Constitution of South Africa), ${ }^{14}$ the Refugees Act No. 130 of 1998 (Refugees Act), ${ }^{15}$ and other national laws that may be relevant to refugees, such as the Aliens Control Act No. 96 of 1991 (Aliens Control Act), as amended, and the Immigration Act No. 13 of 2002 (Immigration Act). ${ }^{16}$ The government of South Africa is obliged to respect and apply this combined legal regime in asylum application procedures.

South Africa became a party to the OAU Convention in December 1995,17 and to both the UN Refugee Convention and the Refugee Protocol in January 1996. ${ }^{18}$ These international instruments, however, required the adoption of "domesticating" legislation in order to become effective within South Africa. The Refugees Act of 1998, which came

11. See Marina Sharpe, Organization of African Unity and African Union Engagement with Refugee Protection: 1963-2011, 21 AFR. J. INT’L \& COMP. L. 50, 55 (2013).

12. See generally REFUGEe LAW IN SOUTH AFRJCA (Fatima Khan \& Tal Hanna Schreier eds., 2014) (analyzing the application for asylum and the rights of refugees in South Africa).

13. G.A. Res. 428 (V) (Dec. 14, 1950). The mandate is to provide, on a non-political and humanitarian basis, international protection to refugees and to seek permanent solutions for them. It has been instrumental in developing standards that States-including some that are not parties to the UN Refugee Convention-have followed in their treatment of refugees and other persons in refugee-like situations.

14. South Africa first adopted the Interim Constitution of the Republic of South Africa, 1993, which came into force on Apr. 27, 1994, the day of the first democratic elections. S. AFR. (INTERIM) CONST., 1993. On May 8, 1996, the Parliament elected in 1994 adopted the Constitution of the Republic of South Africa, 1996. The new constitution was promulgated by President Mandela on Dec. 10, 1996. It came into effect on Feb. 4, 1997, replacing the Interim Constitution of 1993. S. AFR. CONST., 1996.

15. Although signed into law by President Nelson Mandela on Nov. 20, 1998, the Refugees Act No. 130 of 1998 only came into operation on Apr. 1, 2000, following proclamation of the commencement date by the President. See Refugees Act, GG 19544 (2 Dec. 1998) (S. Afr.). The Regulations to the Refugees Act were published on Apr. 6, 1998; see Proclamation No. R. 22 of 2000, GG 21075 (6 Apr. 2000) (S. Afr.).

16. It was signed into law by President Thabo Mbeki on May 30, 2002; see Immigration Act, GG 23478 (31 May 2002).

17. OAU Refugee Convention, supra note 8.

18. UN Refugee Convention and Refugee Protocol, supra note 10. 
into force on April 1, 2000, was adopted for this purpose. ${ }^{19}$ Prior to the enactment of this legislation, persons seeking asylum and refugee status in South Africa were dealt with under the Aliens Control Act, ${ }^{20}$ which was repealed by the Immigration Act in $2002 .{ }^{21}$ Under the post2000 legal regime, any foreigner recognized as a refugee and granted asylum in South Africa is entitled to all the rights set out in the Constitution, except those rights that apply only to South African citizens. ${ }^{22}$

This essay seeks to provide an analysis of how the courts in South Africa have interpreted and applied the legal protection for asylum seekers and refugees enshrined in the Refugees Act, the OAU Refugee Convention, and the UN Refugee Convention since South Africa's accession to the conventions almost a quarter century ago. In particular, the essay discusses how, in practice, the courts have adjudicated upon disputes relating to South African procedures for refugee status determination and related issues.

The discussion proceeds as follows. Part I examines the innovative features of the OAU Refugee Convention, which have partially impacted the scope of international refugee law and are most relevant for the protection of asylum seekers and refugees in African countries parties to the Convention, including South Africa. These features are: the expanded refugee definition; the principle of non-refoulement; the individual right to asylum; and other aspects, such as burden-sharing and temporary protection. Of these features, the expanded refugee definition, the principle of non-refoulement, and temporary protection have been at issue in most of the refugee status determination cases in South Africa.

19. Refugees Act of 1998, supra note 15 .

20. The Aliens Control Act was amended by the Aliens Control Amendment Act 76 of 1995, which was specifically promulgated to bring the Act into conformity with the new, post-apartheid constitutional requirements. Aliens Control Amendment Act 76 of 1995 (S. Afr.).

21. See Minister of Home Affairs v. Eisenberg \& Associates 2003 (5) SA 281 (CC) (S. Afr.).

22. Refugees Act 130 of $1998 \S 27$ (S. Afr.). All foreigners in South Africa are also entitled to these rights. See S. AFR. CoNST., $1996 \S \S 7-37$ (the Bill of Rights, enumerating two types of rights: rights granted to "everyone" and rights limited to "citizens"; examples of rights limited to citizens include the right to vote and universal adult suffrage; the right to stand for public office; the right to free, fair and regular elections; and the right to form, join, and campaign for a political party ( $(19)$; and the right to a passport $(\$ 21(4))$ ). See alsa Union of Refugee Women v. Director: Private Security Industry Regulatory Authority 2007 (4) SA 395 (CC) (S. Afr.); Lawyers for Human Rights v. Minister of Home Affairs 2004 (4) SA 125 (CC) at 6-7 para. 79 (S. Afr.). 
Part II examines the procedures for refugee status determination, both prior to and after the adoption of the Refugees Act, and issues related to the treatment of failed asylum seekers: detention, exclusion, and cessation of refugee status. We also examine other domestic legislation relevant to refugee protection in South Africa. The discussion highlights the failure of the Refugee Status Determination Officers (RSDOs) to understand and apply the principles accurately in the OAU and UN conventions regarding the legal protections for asylum seekers and refugees. It also shows how, by contrast, South African courts have acted as the foremost defenders and enforcers of these legal protections, quite often overruling and setting aside decisions by RSDO that deny the grant of refugee status to asylum seekers who otherwise meet the requirements laid down in the OAU Refugee Convention and UN Refugee Convention.

In Part III, we turn to the provisions in the domestic legislation that incorporate the expanded OAU Refugee Convention definition of a refugee, and the approach of the South African courts in interpreting and enforcing these provisions. The discussion focuses, in particular, on three aspects of the refugee definition that have been at the heart of most refugee status determination claims and decisions by government officials and the courts: events that seriously disturb public order, political opinion, and membership of a particular social group. The various benches of the South African judiciary-the High Court, the Supreme Court of Appeal (SCA), and the Constitutional Court-have built up more refugee jurisprudence in the twenty-five years of the postapartheid era than judiciaries in other refugee-receiving African countries have done over a longer period. However, while this period has witnessed a fair amount of scholarly literature on refugee law and protection in South Africa, there has not been as much extensive analysis of the case law. ${ }^{23}$

We conclude the discussion with the assertion that if the government is unable or unwilling to fulfil its obligations, it falls upon the judiciary to affirm, protect, and enforce the rights of asylum seekers and refugees embodied in the Constitution of South Africa, domestic legislation, and the international treaties to which South Africa is a party. We argue that despite the failures of the executive authorities, in

23. Among scholars that have undertaken some analyses of the South African refugee cases are Roni Amit, No Refuge: Flawed Status Determination and the Failures of South Africa's Refugee System to Provide Protection, 23 INT'L J. REFugee L. 458 (2011); Tal Hanna Schreier, An Evaluation of South Africa's Application of the OAU Refugee Definition, 25 REFUge 53 (2008); Tamara Wood, Expanding Protection in Africa? Case Studies of the Implementation of the 1969 African Refugee Convention's Expanded Refugee Definition, 26 INT'L J. REFUGEE L. 555 (2014). 
particular the RSDOs, and an environment of unmistakable hostility, South African courts continue to play a vanguard role in holding the government accountable for its failure to respect the legal protections of refugees and asylum seekers in accordance with its international treaty obligations.

\section{The OAU REFUgEe CONVENTION: EXPANSION OF THE UN REFUgeE CONVENTION DEFINITION AND OTHER ASPECTS}

When the OAU Refugee Convention was adopted in 1969, international refugee law was still in its early stages of development. A special UN conference had adopted the UN Refugee Convention eighteen years earlier. At the time, only four African countries were members of the UN: Egypt, Ethiopia, Liberia, and the Union of South Africa. By the time that the OAU adopted its regional instrument, only one of the four-Liberia-had ratified the UN Refugee Convention. Although a few other newly independent African states had acceded to the UN Convention in the intervening period, the adoption of the 1969 OAU Convention provided the first occasion that a group of states had cooperated to establish a regional regime for the protection of refugees. Against this background, African states incorporated rules and principles that were strategically formulated to clarify and improve the existing international law on refugee protection that had first been enshrined in the UN Convention. Indeed, the OAU Refugee Convention is described in its own terms in Article VIII(2) as "the effective regional complement in Africa of the UN Convention." ${ }^{24}$ In this respect, the purported improvements relate to, in particular, the following broad clusters of issues: broadening the definition of a refugee; the principle of non-refoulement; the individual right to asylum; and burden-sharing, temporary protection, and voluntary repatriation. We examine each of these in turn in the following sections.

\section{A. Expanding the Definition of a Refugee}

The 1951 UN Refugee Convention defines a refugee as a person who is outside the country of his or her nationality (or place of habitual residence, in the case of stateless persons) due to a "well-founded fear of persecution on account of race, religion, nationality, membership of a

24. Article VIII(2) provides that: "The present Convention shall be the effective regional complement in Africa of the 1951 UN Convention Relating to the Status of Refugees." See OAU Refugee Convention, supra note 8. 
particular social group or political opinion. . . or owing to such fear is unwilling to avail himself or herself of the protection of that country." 25

In their analysis of the UN Refugee Convention definition of a refugee, James Hathaway and Michelle Foster identify seven elements to the definition: (1) alienage, (2) well-founded fear, (3) serious harm, (4) failure of state protection, (5) nexus to civil and political status, (6) needing protection, and (7) deserving protection. ${ }^{26}$ Before proceeding to offer deeply comprehensive analyses of each of these factors in the rest of their seminal treatise, Hathaway and Foster summarize each of the seven elements. First, "alienage" means that the refugee is first and foremost a person outside their country of origin or, in the case of a stateless person, outside their country of former habitual residence. ${ }^{27}$ Second, the requirement of a "well-founded fear" relates to the existence of a "real chance" or objective risk, not subjective fear. ${ }^{28}$ Third, "serious harm"-arguably the central plank of the refugee definition-means that there must be a real risk of being persecuted. ${ }^{29}$ Fourth, "failure of state protection" is a requirement that entails both state unwillingness and state inability to protect the individual. ${ }^{30} \mathrm{Fifth}$, the "nexus to civil and political status" requirement means that any well-founded fear of being persecuted be based on any one of the grounds stipulated in the UN Refugee Convention. ${ }^{31}$ Sixth, "needing protection" is an element that asks whether the person requesting refugee status either has, or can regain, the protection of their own country, or has access to alternative forms of protection tantamount to national protection. ${ }^{32}$ The seventh and final requirement of "deserving protection" addresses the situation whereby an at-risk person may nevertheless be excluded from recognition and protection as a refugee because of their criminal or quasi-criminal actions. ${ }^{33}$

Commentators have criticized the UN Refugee Convention on a number of grounds, three of which stand out. First, its definition of a refugee implies the exclusion of internally displaced persons (IDPs). A persecuted person who fails to fulfil the alienage requirement is an IDP

25. This is a rephrasing of the extensive definition in Article 1(A) of the UN Refugee Convention. For the full text see generally G.A. Res. 429 (V), (July 28, 1951); UN Refugee Convention, supra note 10.

26. James C. Hathaway \& Micherle Foster, The LAW of Refugee Status 13 (2d ed. 2014).

27. $I d$. at 14 .

28. Id.

29. Id.

30. Id.

31. Id. at 15 .

32. Id.

33. Id. 
and does not enjoy the protection of the international refugee law regime. ${ }^{34}$ Second, the picture that emerges from the jurisprudence in Western countries and from the scholarship is that the meaning of "well-founded fear of persecution" is contested. For example, it seems clear that "well-founded fear of persecution" analytically consists of three elements, namely (1) "well-founded fear" (that is genuine risk), (2) "being persecuted" (that is the existence of serious harm), and (3) "failure of state protection." While nearly all courts apply all these three elements, the jurisprudence under each element has diverged considerably, and not all courts evaluate the failure of state protection in the analysis of persecution. Third, the UN Refugee Convention's requirement that the refugee's persecution have a nexus to one or more of the refugee's civil or political characteristics excludes persons fleeing other kinds of life-threatening conditions or situations (such as famine, drought, or environmental disasters). It also excludes migrants who flee their countries primarily to escape harsh economic conditions and seek opportunities for an improved standard of living elsewhere. Arguably, many-perhaps a majority—of the African migrants that have made or attempted the perilous journey across the Mediterranean Sea into Europe in recent years belong to this category. Such migrants are commonly referred to as "economic refugees." 35

So how does the OAU Refugee Convention change this? Substantively, the OAU Refugee Convention expands the definition of a refugee. While Article I, paragraph 1 of the OAU Refugee Convention essentially reproduces the UN Refugee Convention definition, ${ }^{36}$ Article I, paragraph expands this definition as follows:

34. The subsequent practice has been for the United Nations High Commission for Refugees (UNHCR), at the request of the UN Secretary-General and the General Assembly, to extend its mandate to IDPs. See TMANJANA MALUWA, INTERNATIONAL LAW IN POST-CoLONIAL AFRICA 178 (1999); Arthur C. Helton, What is Refugee Protection?, INT'L J. REFUGEE L. 119, 120 (1990).

35. See generally ALAN DOWTY, ClOSED BORDERS: THE CONTEMPORARY ASSAULT ON FREEDOM OF MOVEMENT (1987); Elizabeth G. Ferris, Overview: Refugees and World Politics, in REFugeEs AND WORLD POLITICS (Elizabeth G. Ferris ed. 1985); LEON GORDENKER, REFUGEES IN INTERNATIONAL POLITICS (1987); Andrew E. Shacknove, Who is a Refugee?, 95 ETHICS 274 (1985) (discussing how refugees are dealt with in the international community); see also MALUWA, supra note 34, at 178 .

36. OAU Convention, Article I(1) provides: "For the purposes of this Convention, the term 'refugee' shall mean every person who, owing to well-founded fear of being persecuted for reasons of race, religion, nationality, membership of a particular social group or political opinion, is outside the country of his nationality and is unable or, owing to such fear, is unwilling to avail himself of the protection of that country, or who, not having a nationality and being outside the country of his former habitual residence as a result of such events is unable or, owing to such fear, is unwilling to return to it." 
The term "refugee" shall also apply to every person who, owing to external aggression, occupation, foreign domination or events seriously disturbing public order in either part or the whole of his country of origin or nationality, is compelled to leave his place of habitual residence in order to seek refuge in another place outside his country of origin or nationality. .37

The OAU Refugee Convention definition aimed to include people who were forced into flight from African countries that were still engaged in anti-apartheid and anti-colonial liberation struggles, and to include those fleeing civil wars in their countries. ${ }^{38}$ Historical context shaped the contours of this definition. ${ }^{39}$ The need to respond to the reality of the African continent at the time-armed conflict arising from anti-colonial struggles, internal civil wars, and the resulting exoduseswere overriding considerations for the new definition. ${ }^{40}$ Tamara Wood describes the context of the adoption of the OAU Refugee Convention as follows:

The context of the Convention's adoption is well understood. In 1969, Africa was a continent still very much engaged in the process of decolonization; many African states continued to struggle against colonial and minority powers and this led to frequent movements of people, as many left their countries to escape colonial oppression. ${ }^{41}$

Indeed, it has been noted that the "specific aspects" referred to in the very title of the OAU Refugee Convention "were largely the result of persistent colonial domination and minority rule on the continent." 42 Medard Rwelamira describes this historical context thus:

[The] question of whether the African Convention extends protection to persons engaged in military struggle remains a controversial one. [This] issue was

37. Id. at art. (I)(2).

38. See generally Sharpe, supra note 11, at 55-69 (discussing the legislative history of the OAU Refugee Convention refugee definition).

39. Eduardo Arboleda, Refugee Definition in Africa and Latin America: The Lessons of Pragmatism, 3 INT'L J. REFUGEE L. 185, 192 (1991).

40. MALUWA, supra note 34 , at 180.

41. Wood, supra note 23 , at 557.

42. Sharpe, supra note 11 , at 66 . 
discussed at length at the Conference on the Legal, Economic and Social Aspects of African Refugee Problem held in Addis Ababa in 1967. General consensus existed that the question of freedom fighters was intricately linked to the question of subversion. While support of freedom fighters intent on overthrowing a government of an independent states could not conceivably be condoned in any way, it was accepted unreservedly that in a spirit of African solidarity it was the duty of every African country to assist freedom fighters who were fighting for the liberation of the African continent from colonial and racial domination. [It] was against this background that Article I(2) was added to the general refugee definition from the 1951 Convention. ${ }^{43}$

The OAU Refugee Convention's expansion of the refugee definition improves upon the UN Refugee Convention definition by explicitly introducing objective criteria for determining refugee status that are dependent on the prevailing situations in the refugee's country of origin. ${ }^{44}$ As Eduardo Arboleda has pointed out, "[The] new definition of refugee is qualitatively different from the classical definitions[,] for it considers situations where the qualities of deliberateness and discrimination need not be present." ${ }^{45}$ The generalized nature of the refugee-generating events-external aggression, occupation, foreign domination, and events seriously disturbing public order-means that the definition provides better protection to persons fleeing widespread or indiscriminate forms of harm, such as civil war. ${ }^{46} \mathrm{~A}$ nontrivial

43. Medard R. Rwelamira, Some Reflections on the OAU Convention on Refugees: Some Pending Issues, 16 COMP. \& INT'L L. J. S. AFR. 155, 169 (1983).

44. See generally Emmanuel Opoku Awuku, Refugee Movements in Africa and the $O A U$ Convention on Refugees, 39 J. AFR. L. 79, 80 (1995); George Okoth-Obbo, Thirty Years On: A Legal Review of the 1969 OAU Convention Governing the Specific Aspects of Refugee Problems in Africa, 20 REFUGEE SURV. Q. 79 (2001); Micah B. Rankin, Extending the Limits or Narrowing the Scope? Deconstructing the OAU Refugee Definition Thirty Years On, 21 S. AFR. J. HUM. RTS. 406 (2005); Bahame T. Nyanduga, Refugee Protection under the 1969 OAU Convention Governing the Specific Aspects of Refugee Problems in Africa, 47 GERMAN Y.B. INT'L L. 85, 86 (2004) (analyzing the OAU and its approach to and management of refugee issues).

45. See Arboleda, supra note 39, at 195.

46. Alice Edwards, Refugee Status Determination in Africa, 14 AFR. J. INT'L \& COMP. L. 204, 221 (2006); Okoth-Obbo, supra note 44, at 112. See also Office of the United Nations High Comm'r for Refugees, Handbook on Procedure and Criteria for Determining Refugee Status, fi 164, U.N. Doc. HCR/1P/4/Eng/REV.1 (1992) [hereinafter UNHCR HANDBOOK]. The UNHCR HANDBOOK is intended as a guide for government officials dealing with the 
construction of this definition also covers individuals forced to flee from their countries of origin or habitual residence due to other factors, such as environmental and other humanitarian disasters. ${ }^{47}$ Moreover, as is widely accepted, the OAU Refugee Convention's expanded refugee definition is particularly suited to group-based refugee status determination and better protection in situations of mass influx. ${ }^{48}$ Mass influx has characterized most refugee movements in Africa in the past and continues to the present day.

Equally important, the requirement that the relevant event occur in either "the whole or part" of the refugee's country of origin removes the so-called "internal protection alternative" (sometimes referred to as "internal flight" or "internal relocation"). James Hathaway and Michelle Foster have noted that some states construe the internal protection alternative as implied in the UN Refugee Convention definition and that according to those states, the internal protection alternative requires a refugee to seek protection, first, elsewhere within their own country before they may qualify for refugee status in another country. 49 But the UN High Commissioner for Refugees (UNHCR) has rejected the internal protection alternative. Rather, the UNHCR holds the view that the internal protection alternative is not a necessary part of the UN Refugee Convention's refugee definition and that it cannot be used to undermine the UN Refugee Convention's aims or international human rights norms. ${ }^{50}$ The OAU Refugee Convention is unique in removing this possibility. ${ }^{51}$

In brief, the expanded definition in the OAU Refugee Convention provides a pragmatic solution to the problem of determining refugee

determination of refugee status. Some judges in South Africa have invoked it in their judicial decisions. See infra note 273.

47. Some writers argue that Article I(2) of the OAU Refugee Convention definition should be construed to allow for protection of persons displaced by environmental disasters or climate change. See, e.g., Jessica B. Cooper, Environmental Refugees: Meeting the Requirements of the Refugee Definition, 6 N.Y.U. ENVTL. L.J. 480, 499 (1998); Alice Edwards, Refugee Status Determination in Africa, 14 AFR. J. INT'L \& COMP. L. 204, 206 (2006); Carlas Ortiz Miranda, Toward a Broader Definition of Refugee: 20th Century Development Trends, 20 CAL. W. INT'L L.J. 315, 326-27 (1989).

48. See IVOR JACKSON, THE REFUGEE CONCEPT IN GROUP SiTUATIONS 193 (1999); Anais Tuepker, On the Threshold of Africa: $O A U$ and UN Definitions in South African Asylum Practice, 15 J. REFUGEE STUD. 409, 411 (2002).

49. See HATHAWAY \& FosTER, supra note 26, at 14-15, 332-61.

50. See Office of the United Nations High Comm'r for Refugees, Guidelines on International Protection: Internal Flight or Relocation Alternative within the Context of Article 1(A)(2) of the 1951 Convention and/or 1967 Protocol relating to the Status of Refugees, I4, U.N. Doc. HCR/GIP/03/04 (2003).

51. See id. I 5 ("Consideration of possible internal relocation areas is not relevant for refugees coming under the purview of Article I(2)."). 
status during times of mass migrations or forced human population displacement when individual determinations are impractical, inadequate, or totally absent. ${ }^{52}$ The definition also breaks new ground in international law by embracing an additional category of persons as refugees: namely, all those who are compelled to leave their country of origin in order to escape violence, regardless of a specific connection to political or civil status.

It is important to recall that the drafters of the OAU Refugee Convention definition employed terms such as "external aggression," "occupation," and "foreign domination" at a time when they had not acquired widely agreed or settled meanings in international law. ${ }^{53}$ Clearly, the reference to these terms pointed at the historical situation in some African states-especially in southern Africa-that were still under colonial rule, foreign occupation, or governed by minority racist regimes: South Africa, Southern Rhodesia (Zimbabwe), South West Africa (Namibia), and the various Portuguese African colonies. ${ }^{54}$ These countries were theaters of national liberation wars, and the OAU's expanded refugee definition extended protection to both freedom fighters and to their supporters. 55 The incidents of intra-African conflicts in the African Great Lakes region and the massive refugee movements those conflicts have generated during the last two-and-ahalf decades have been a reminder of this problem and the continuing relevance of the expanded OAU refugee definition.

In this respect, the drafters of the definition did not primarily consider the strict legal meaning of its terminology and case law, but were rather more concerned with providing a flexible and pragmatic solution to the protection of asylum seekers and refugees. ${ }^{56}$ At the same time, however, Adetola Onayemi and Olufemi Elias have rightly pointed out that this does not mean that the OAU Refugee Convention establishes a lax regime. ${ }^{57}$ On the contrary, while the OAU Refugee Convention broadens the definition in certain respects, it also expands

52. Arboleda, supra note 39 , at 195 .

53. MaLUWA, supra note 34 , at 180 .

54. See Rwelamira, supra note 43 (discussing the relevance of the struggles against colonialism, apartheid, and racist minority rule in these southern African countries as a factor in the adoption of the OAU Refugee Convention and its expanded refugee definition); see also Sharpe, supra note 11, at 55-69 (discussing the legislative history of the Convention and its refugee definition).

55. See Rwelamira, supra note 43.

56. Arboleda, supra note 39 , at 195 .

57. Adetola Onayemi \& Olufemi Elias, Aspects of Africa's Contribution to the Development of International Law, in SHIELDING HUMANITY: ESSAYS IN INTERNATIONAL LAW IN HONOUR OF JUDGE ABDUL G. Koroma 591, 595 (Charles C. Jalloh \& Olufemi Elias eds., 2015). 
the permissible bases for which a hosting State may revoke status or exclude a refugee in the first place. ${ }^{58}$

Scholars of refugee law and refugee studies, as well as experts and institutions concerned with refugees, have commended the OAU Refugee Convention's definition since its adoption as a significant normative development in international refugee law. ${ }^{59}$ Scholarly commentaries have also celebrated the innovative character of the OAU Refugee Convention, especially the expanded refugee definition, and reaffirmed its status as a regional complement to the UN instrument. ${ }^{60}$

58. Compare OAU Refugee Convention, art. 1(4)(f),(g), with UN Refugee Convention, art. 1.C, F. The OAU Refugee Convention ceases to apply to any refugee who has "committed a serious non-political crime outside his country of refuge after his admission to that country as a refugee" or has "seriously infringed the purposes and objectives of the Convention." OAU Refugee Convention, supra note 8. In terms of Article 1.C, the UN Refugee Convention ceases to apply to any refugee who has "voluntarily re-availed himself of the protection of the country of his nationality," or has "voluntarily re-acquired it," or has "acquired a new nationality and enjoys the protection of the country of his new nationality," or has "voluntarily re-established himself in the country which he left or outside which he remained owing to fear of persecution," or "can no longer, because circumstances in connection with which he has been recognized as a refugee have ceased to exist, continue to refuse to avail himself of the protection of the country of his nationality," or being a person who has no nationality he is, because the circumstances in connection with which he has been recognized as a refugee have ceased to exist, is able to return to the country of his former habitual residence." U.N. Refugee Convention, supra note 10, at art. 1(C). Article 1.F provides that the UN Refugee Convention shall not apply to any person with respect to whom there are serious reasons for considering that "(a) he has committed a crime against peace, a war crime, or a crime against humanity, as defined in the international instruments drawn up to make provision in respect of such crime; (b) he has committed a serious non-political crime outside the country of refuge prior to his admission to that country as a refugee; (c) he has been guilty of acts contrary to the purposes and principles of the United Nations." Id. at art. 1(F).

59. See, e.g., HATHAWAY \& FOSTER, supra note 26 , at 2, n. 7 .

60. There is a copious scholarly literature on the OAU Refugee Convention dating from the earliest years following its adoption. See, e.g., Ousmane Goundiam, African Refugee Convention, 2 MIGRATION NEWS 7 (1970); Paul Weis, The Convention of the Organisation of African Unity Governing the Specific Aspects of Refugee Problems in Africa, 3 REV. DE DROITS DE L'HOMME 449 (1970); Medard R. Rwelamira, Two Decades of the 1969 OAU Convention Governing the Specific Aspects of Refugee Problems in Africa, 1 INT'L J. REF. L. 557 (1989); Joe Oloka-Onyango, Human Rights, OAU Refugee Convention and the Refugee Crisis in Africa: Forty Years After Geneva, 3 INT'L J. REF. L. 453 (1991); Rainer Hofmann, Refugee Law in the African Context, 52 HEDELBERG J. INT'L L. 318 (1992); Christopher J. Bakwesega, The $O A U$ and African Refugees, in THE ORGANIZATION OF AFRICAN UNITY AFTER THIRTY YEARS 77 (Yassin El-Ayouty ed., 1994); Okoth-Obbo, supra note 44; Rankin, supra note 44; and Marina Sharpe, The 1969 African Refugee Convention: Innovations, Misconceptions, and Omissions, 58 MCGILL L.J. 97 (2012). But see Sharpe, at 111-124 (acknowledging and discussing the OAU Refugee Convention's significant contributions to refugee protection in Africa and its major legal innovations, but arguing that one of the Convention's most misunderstood aspects is the notion that its definition of a refugee is much broader than that in the UN Refugee Convention). 
The UNHCR's recognition of the normative importance of the OAU Refugee Convention's definition was underscored by António Guterresthe UN High Commissioner for Refugees-in 2014 during the commemoration of the fortieth anniversary of its adoption when he declared that the Convention "is considered one of the most generous and flexible documents on refugee protection."61

Finally, the influence of the OAU's expanded definition, can specifically be seen through its incorporation into the domestic legislation of countries both in Africa ${ }^{62}$ and, in at least one case, outside Africa. ${ }^{63}$ It has also informed developments at the multilateral level, both internationally and regionally. Most notably, it has provided the basis for the expanded definition of refugee in the Draft Convention on Territorial Asylum adopted by the UN General Assembly in 1977.64

61. See UNHCR Press Release, UN High Commissioner for Refugees Lauds Africa Refugee Convention, at 40, for Saving Millions of Lives (June 18, 2014).

62. See generally Refugee Act of 1996, No. 13 (2006) THE LAWS OF KENYA, REVISED EDITION $\S 291$; Refugee Act, No. 3 of 1989 § 291 (1989) (Malawi); National Commission for Refugees (Establishment, Etc.) Act (1989) Cap. N 21 LFN 2004 (Nigeria); Refugees Act 130 of $1998 \S 3$ (S. Afr.). With 46 ratifications, the OAU Refugee Convention has the third largest number of parties of any OAU or AU treaty, save for the AU Constitutive Act and the African Charter on Human and Peoples' Rights. For the status list of the OAU Refugee Convention, see OAU/AU Treaties, Conventions, Protocols \& Charters, AFR. UNION, https://au.int/treaties (last visited Mar. 29, 2020).

63. See generally Refugees Act, No. 26 of $1991 \S 4(1)$ (c) (1991) (Belize). Mexico initially incorporated, by general reference, the Cartagena Declaration, infra note 63 , into its domestic law through the Decree of Jul. 17, 1990, thereby indirectly adopting the Declaration's expanded refugee definition, which is in turn based on the OAU Refugee Convention's definition. See generally J.F. Durieux, Capturing the Central American Refugee Phenomenon: Refugee Law-Making in Mexico and Belize, 4 INT'L J. REFUGEE L. 301 (1992) (discussing the inadequacy of traditional refugee definitions). In 2010, Mexico's National Assembly adopted new legislation, drafted with the technical support of UNHCR: The Law on Refugees, Complementary Protection, and Political Asylum. See Kausha Luna, Mexico's Refugee Law, available at http://www.cis.org/Luna/Mexicos-Refugee-Law. It was signed into law on Dec. 26, 2011. Article 13 of this law specifically incorporates the broader refugee definition and the protections provided for asylum seekers in the Cartagena Declaration using the language of the Declaration. Ley Sobre Refugiados, Protección Complementaria Y Asilo Político, Articulo13, Diario Oficial de la Federación [DOFI 27-1-2011, últimas reformas DOF 30-10-2014 (Mex.).

64. U.N. Conference on Territorial Asylum, 1977 Draft UN Convention on Territorial Asylum, U.N. Doc. A/CoNF.78/12 (Apr. 21, 1977). In terms of Article 2(1): "Each Contracting State may grant the benefits of this Convention to a person seeking asylum, if he, being faced with a definite possibility of: (a) Persecution for reasons of race, colour, national or ethnic origin, religion, nationality, kinship, membership of a particular social group or political opinion, including the struggle against colonialism and apartheid, foreign occupation, alien domination and all forms of racism; or (b) Prosecution or punishment for reasons directly related to the persecution set forth in (a); is unable or unwilling to return to the country of his nationality, or, if he has no nationality, the country of his former domicile or habitual residence." Id. at art. 2(1). 
In 1984, the Organization of American States followed suit and adopted a similar definition in the Cartagena Declaration on Refugees. ${ }^{65}$ Some commentators have noted that the OAU's expanded refugee definition has provided practical guidance to the UNHCR. ${ }^{66}$ In her study examining African state practice and UNHCR's practice in carrying out its refugee status determination function, Marina Sharpe has observed that the UNHCR has adopted a wider refugee definition based on the definitions in the OAU Refugee Convention and the Cartagena Declaration. ${ }^{67}$ Thus, in practical terms, this has extended the UNHCR's mandate to a variety of situations of forced displacement resulting from conflict, indiscriminate violence, or public disorder. ${ }^{68}$

\section{B. Reaffirming the Principle of Non-Refoulement}

The principle of non-refoulement, as articulated in Article 33 of the UN Refugee Convention, prohibits states from returning refugees to territories where the life or freedom of the refugee may be threatened on account of race, religion, nationality, or membership of a particular social group or political opinion. ${ }^{69}$ It is widely recognized as the

65. Adopted at the Colloquium on International Protection of Refugees and Displaced Persons in Central America, Mexico and Panama, held in Cartagena, Colombia, Nov. 1922, 1984. See Eduardo Arboleda, The Cartagena Declaration of 1984 and its Similarities to the 1969 Convention - A Comparative Perspective, INT'L J. REFUGEE L. 87, 94 (1995). See also Sharpe, supra note 60, at 103.

66. See, e.g., Marina Sharpe, The 1969 OAU Refugee Convention and the Protection of People Fleeing Armed Conflict and Other Situations of Violence in the Context of Individual Refugee Status Determination, UNHCR 15-16 (2013), https://www.unher.org/ en-us/protection/globalconsult/50f9652e9/30-1969-oau-refugee-convention-protection-

people-fleeing-armed-conflict.html.

67. Id. at 15 ("In its RSD operations, UNHCR has adopted a wider refugee definition, based on the definitions in the 1969 Convention and the 1984 Cartagena Declaration on Refugees.").

68. Id. at 16 (citing UN High Commissioner for Refugees, MM (Iran) v Secretary of State for the Home Department - Written Submission on Behalf of the United Nations High Commissioner for Human Refugees, C5/2009/2479, at 10 (Aug. 3, 2010), available at http://www.unhcr.org/refworld/docid/4c6aa7db2.html).

69. The principle is framed in Article 33 as follows: "(1) No Contracting State shall expel or return ("refouler") a refugee in any manner whatsoever to the frontiers of territories where his life or freedom would be threatened on account of his race, religion, nationality, membership of a particular social group or political opinion. (2) The benefit of the provision may not, however, be claimed by a refugee whom there are reasonable grounds for regarding as a danger to the security of the country in which he is, or who; having been convicted by a final judgment of a particularly serious crime, constitutes a danger to the community of that country." UN Refugee Convention, supra note 10, at art. 33. 
cornerstone of international refugee protection. ${ }^{70}$ The OAU Refugee Convention not only strengthens the institution of asylum, but it also strengthens the principle of non-refoulement.

The principle of non-refoulement is a major aspect of the concept of asylum, and is enshrined in both international refugee treaties and international human rights treaties. ${ }^{71}$ The formulation of the principle in Article II, paragraph 3 of the OAU Refugee Convention draws on Article 3, paragraph 1 of the UN Declaration on Territorial Asylum. The latter provides that "[n]o person referred to in article 1, paragraph 1, shall be subjected to measures such as rejection at the frontier or, if he [or she] has already entered the territory in which he seeks asylum, expulsion or compulsory return to any state where he may be subjected to persecution." 72 For its part, the OAU Refugee Convention provides that:

No person shall be subjected by a Member State to measures such as rejection at the frontier, return or expulsion, which would compel him to return to or remain in a territory where his life, physical integrity or liberty would be threatened for reasons set out in Article I, paragraphs 1 and 2.73

There are three main reasons that the OAU Refugee Convention strengthens the principle of non-refoulement. First, the OAU Refugee Convention, unlike under the UN Refugee Convention, describes the people to whom non-refoulement applies as "persons" and not

70. Elithu LAUTERPaCHT \& DANIEL BETHLEHEM, REFUgeE PROTECTION IN INTERNATIONAL LAW: UNHCR'S GLOBAL CONSULTATIONS ON INTERNATIONAL PROTECTION 87-177 (Erika Feller et al. eds., 2003). See generally CORNELIS WOLFRAM WOUTERS, INTERNATIONAL LEGAL STANDARDS FOR THE PROTECTION FROM REFOULEMENT (2009) (exploring the basic right of every forcibly-displaced person to be protected from refoulement).

71. Apart from the UN Refugee Convention and the OAU Refugee Convention, the principle of non-refoulement is also enshrined in some human rights treaties: International Covenant on Civil and Political Rights of 1966, art. 7, Dec. 19, 1966, 999 U.N.T.S. 171; Convention Against Torture and Other Cruel, Inhuman and Degrading Treatment or Punishment of 1984, art. 3, Dec. 10, 1984, 1465 U.N.T.S. 85; Convention on the Rights of the Child, art. 6, 37, Nov. 20, 1989, 1577 U.N.T.S. 3; International Convention for the Protection of All Persons from Enforced Disappearance, art. 16, Dec. 20, 2006, 2716 U.N.T.S. 3.

72. U.N. General Assembly, Declaration on Territorial Asylum, A/RES/2312(XXII) (14 Dec. 1967), art. 3(1), available at https://www.refworld.org/docid/3b00f05a2c.html.

73. OAU Refugee Convention, art. II(3), supra note 8. 
"refugees"74-persons therefore do not need refugee status to be eligible for non-refoulement under the OAU Refugee Convention. Consequently, the OAU Refugee Convention's regime offers protection to a wider range of persons than its UN counterpart, given its broadened refugee definition. ${ }^{75}$ Second, the OAU Refugee Convention expands nonrefoulement because it does not include a national security exception, as is provided for under Article 33(2) of the UN Refugee Convention. ${ }^{76} \mathrm{~A}$ third, somewhat subtle, difference is between the text of Article 33, paragraph 1 of the UN Refugee Convention and Article II, paragraph 3 of the OAU Refugee Convention. Whereas the former prohibits return to territories where life or freedom would be threatened, the latter could be interpreted as prohibiting return to territories where life, physical integrity, and liberty would be threatened. Arguably, a prohibition on return in the face of threats to physical integrity provides a wider ambit of protection than a prohibition on return in the face of threats to life. ${ }^{77}$ Furthermore, consistent with its approach to strengthening the principle of non-refoulement, the OAU Refugee Convention explicitly enshrines voluntary repatriation in its Article V, paragraph 1, which provides that "the essentially voluntary nature of repatriation shall be respected in all cases and no refugee shall be repatriated against his will." Functionally, the principle of non-refoulement and the prohibition of involuntary return or forced repatriation provide the same scope of protection.

But the notion that the OAU Refugee Convention expands the principle of non-refoulement needs to be taken with a caveat. Some commentators have argued that the OAU Refugee Convention, like its UN counterpart, allows expulsion, or refoulement, in limited circumstances, except that the OAU Refugee Convention does so only indirectly. ${ }^{78}$ And as Guy Goodwin-Gill and Jane McAdam argue, even

74. W.J.E.M. van Hövell tot Westerflier, Africa and Refugees: The OAU Refugee Convention in Theory and Practice, 7 NETH. Q. HUM. RTS. 172, 176 (1989).

75. Marina Sharpe, African Union Refugee Definition, RTS. IN EXIE PRocRAMME, http://www.refugeelegalaidinformation.org/african-union-refugee-

definition\#sthash.vVieaCap.pdf (last visited Feb. 16, 2020).

76. UN Refugee Convention, supra note 10, at art. 33(2).

77. See, e.g., Georges Abi-Saab, The Admission and Expulsion of Refugees with Special Reference to Africa, 8 AFR. Y.B. INT'L L. 89, 90 (2000); Arboleda, supra note 39, at 185; Rachel Murray, Refugees and Internally Displaced Persons and Human Rights: The African System, 24 REFUGEe SURV. Q. 56, 57 (2005); George Okoth-Obho, The OAU/UNHCR Symposium on Refugees and Forced Population Displacements in AfricaA Review Article, INT'L J. REFUGEE L. 274, 287-89 (1995); Wood, supra note 23 (discussing some of the innovative aspects of the OAU Refugee Convention).

78. Rose M. D'Sa, The African Refugee Problem: Relevant International Conventions and Recent Activities of the Organization of African Unity, 31 NETH. INT'L L. REV. 378, 388 (1984). 
under the UN Refugee Convention, non-refoulement applies equally to refugees and asylum seekers, "at least during an initial period and in appropriate circumstances, for otherwise there would be no effective protection." 79 In this respect, it is necessary to recall the difference between these two classes of persons. On the one hand, a refugee is someone who factually fulfils the requirements of the refugee definition set out in the UN Refugee Convention or the OAU Refugee Convention, as the case may be. ${ }^{80}$ The defining factor is not the recognition by the host state, but rather the fact of fulfilling the requirements. ${ }^{81} \mathrm{On}$ the other hand, an asylum seeker is someone who claims to be a refugee but whose claim has not been definitively evaluated. Further, while it is true that the OAU Refugee Convention does not include a national security exception, sections ( $f$ ) and (g) of its Article I, paragraph undercut claims that this exclusion reduces refoulement. Under these provisions, the application of the Convention-and thus the protection afforded by non-refoulement-ceases if the person concerned commits a serious nonpolitical crime outside the country of refuge after admission as a refugee or seriously infringes the Convention's purposes and objectives. In this sense, therefore, the OAU Refugee Convention's expanded principle of non-refoulement is not as absolute as some scholars make it out to be. ${ }^{82}$

\section{Exploring the Right to Asylum}

It is widely acknowledged that the UN Refugee Convention does not establish a right to asylum for the individual, and that no other international instrument of universal scope recognizes such a right. The Convention lays out an obligation upon the States Parties not to return asylum seekers admitted to their territories to places where their lives or freedom may be in danger (the principle of non-refoulement) but does not oblige them to admit refugees. The duty placed upon States Parties,

79. GUY S. GOODWIN-GILL \& JANE MCADAM, THE REFUGEE IN INTERNATIONAL LAW 232 (3d ed. 2007).

80. OAU Refugee Convention, supra note 8, art. I; UN Convention Refugee Convention, supra note 10, art. 1(A)(2); see also UNHCR Handbook, supra note 46, at paras. 195-05 (setting out the principles and methods for establishing the facts when determining refugee status).

81. See Saidi v Minister of Home Affairs 2018 (4) SA 333 (CC) at para. 34 (S. Afr.) (quoting Judge Pinto de Albuquerque of the European Court of Human Rights in Hirsi Jamaa v Italy [GC], No. 27765/09, ECHR 2012, at 63: "[a] person does not become a refugee because of recognition, but is recognised because he or she is a refugee.")

82. See, e.g., Murray, supra note 77. 
implied in Articles 1 and 33 of the UN Refugee Convention, is only to grant access to asylum procedures to asylum seekers. ${ }^{83}$

The UN General Assembly adopted the UN Refugee Convention three years after the 1948 adoption of the Universal Declaration of Human Rights (UDHR) ${ }^{84}$ Article 14, paragraph 1 of the UDHR provides for the right of individuals to seek and enjoy asylum, but it does not positively oblige states to provide it. The UDHR contains no express provision that stipulates an obligation upon states to grant asylum. Recalling the legislative history of article 14, paragraph 1 Roman Boed has noted that:

The drafting history of Article 14(1), however, reveals that the drafters of the Declaration contemplated-but ultimately declined to adopt-any significant innovation in the law of asylum. The original draft of Article 14 provided that, "[e]veryone has the right to seek and to be granted, in other countries, asylum from persecution." This generous provision would have vested individuals with the right to asylum vis-à-vis the state of refuge. ${ }^{85}$

Some sixteen years after the adoption of the UN Refugee Convention, the General Assembly adopted the Declaration on Territorial Asylum, which also did not recognize an individual right to asylum. ${ }^{86}$ No other UN instrument has codified the right. Consequently, Goodwin-Gill and McAdam, among the leading authorities on the subject, have made the categorical and widely shared conclusion that, based on state practice, there is no right to asylum. ${ }^{87}$ Nevertheless, Ousmane Goundiam has advanced the case for a right to asylum on the basis that asylum is "the first and most fundamental of the refugee's

83. The view that the UN Refugee Convention and the Refugee Protocol do not provide a right to be granted asylum is shared by most scholars and writers and has not been seriously challenged. See, e.g., Roman Boed, The State of the Right of Asylum in International Law, 5 DUKE J. COMP. \& INT'L L. 1, 11 (1994). See also David A. Martin, Reforming Asylum Adjudication: On Navigating the Coast of Bohemia, 138 U. PA. L. REV. 1247, 1255 (1990) (noting that classically the right to asylum under international law belonged to the States and not to individuals).

84. G.A. Res. 217 (III) A, Universal Declaration of Human Rights (Dec. 10, 1948).

85. Boed, supra note 83 , at 9 .

86. See G.A. Res. 2312 (XXII), Declaration on Territorial Asylum (Dec. 14, 1967).

87. See GOODWIN-GILL \& MCADAM, supra note 79, at 132; see also María-Teresa GilBazo, Asylum as a General Principle of International Law, 27 INT'L J. REFUGEE. L. 3, 5-6 (2015); María-Teresa Gil-Bazo, Refugee Status, Subsidiary Protection, and the Right to be Granted Asylum Under EC Law, UNHCR 7 (Nov. 2006), https://www.unhcr.org/enus/research/working/455993882/refugee-status-subsidiary-protection-right-grantedasylum-under-ec-law.html. 
needs and to grant him this constitutes the preliminary condition for him to have all the other rights." 88

The OAU Refugee Convention does not depart from the established consensus that the so-called right to asylum is really the right of refugees to petition States to grant them asylum if the States wish to do so, as an exercise of their sovereign choice. Thus, the OAU Refugee Convention provides that:

\begin{abstract}
Member States of the OAU shall use their best endeavors consistent with their respective legislation to receive refugees and to secure the settlement of those refugees who, for well-founded reasons, are unable or unwilling to return to their country of origin or nationality. ${ }^{89}$
\end{abstract}

In essence, the OAU Refugee Convention merely urges States to grant asylum but does not create a right enforceable by the individual against the State. The appeal to States to "[use] their best endeavors" suggests that it merely grants a permissive right on the part of the State rather than a positive, enforceable right on the part of the individual. Hence, Abdulqawi Yusuf observed that the OAU Refugee Convention "strengthens the institution of asylum and broadens the scope of the 1951 Convention in this respect by providing for the 'right to grant asylum." 90 Nevertheless, Cristiano D'Orsi has argued that this provision serves as "a further inroad into the traditional international law perspective which has tended to regard asylum as an exclusive right of the sovereign State, and certainly not as a right to be enforced by an individual against a State."91

88. See Goundiam, supra note 60 , at 9.

89. OAU Refugee Convention, art. II(1), supra note 8.

90. Abdulqawi A. Yusuf, The Public Law of Africa and International Law: Broadening the Scope of Application of International Rules and Enriching Them for Intra-Africa Purposes, in SHIELDING HUMANITY: ESSAYS IN INTERNATIONAL LAW IN HONOUR OF JUDGE ABDUL G. KoROMA 513, 518 (Charles C. Jalloh \& Olufemi Elias eds., 2015). Hofmann makes a similar observation; see Hofmann, supra note 60, at 34 .

91. See CRISTIANo D'ORSI, ASYLUM-SEEKER AND REFUgeE Protection IN SubSAHARAN AFRICA 33-40 (2015). The argument that the individual possesses a right to asylum, which the State must grant as a matter of duty, has a long history. See HuGo GROTIUS, ON THE LAW OF WAR AND PEACE 218 (A.C. Campbell trans. 2001) (arguing that the right to asylum is a natural right open to victims of unmerited persecution and that states have a corresponding duty to grant asylum). Of course, such a right might be enforceable by the individual if codified in the domestic legislation of the host State, and if the individual is already on its territory and able to process an asylum application. See Onayemi \& Elias, supra note 57, at 596 ("It can be favorably argued that there are prospects under Article 2(1) for the right to asylum to be enforced by an individual against 
While the OAU Refugee Convention does not enshrine a positive individual right to asylum, it does characterize the grant of asylum as a "peaceful and humanitarian act" that "shall not be regarded as an unfriendly act by any Member State." ${ }^{2}$ Most African s have generally respected this peaceful and humanitarian character of asylum, even if the levels of refugee protection in recent years have declined due to lack of-or limited-resources, and other challenges faced by these States. While, in practical terms, this may not be different from the treatment extended under the UN Refugee Convention, the inclusion of this element in the OAU Refugee Convention provides an added consideration to the way States treat asylum seekers. This is particularly relevant with respect to the few African States that are parties to the OAU Refugee Convention, but not to the UN Refugee Convention..$^{93}$

The first, and so far only, international instrument to enshrine an individual right to asylum is the African Charter on Human and Peoples' Rights (African Charter). ${ }^{94}$ Article 12, paragraph 3 of the African Charter provides that "[e]very individual shall have the right, when persecuted, to seek and obtain asylum in other countries in accordance with the law of those countries and international conventions." Although the incremental advances made by the OAU Refugee Convention appear to have culminated in the codification of a right to asylum in the African Charter, stricter analysis of this provision paints a mixed picture. The right "to seek and obtain" asylum, articulated in Article 12, paragraph 3 of the African Charter, suggests a deliberate intention by the drafters to incorporate the language that was rejected by the drafters of Article 14, paragraph 1 of the UDHR ("to seek and be granted"). ${ }^{95}$ On the one hand, the right of an individual who is suffering persecution to seek asylum is not controversial, nor open to debate, since it is an aspect of the right of the individual to leave any country, including their own. On the other hand, the notion of a right to "obtain" asylum remains untenable. As noted earlier, there is no corresponding obligation under general international law on states to admit refugees, and this discretionary power has not been questioned or

a State in which the 1969 Convention has been transformed into, or is otherwise applicable, as domestic law."). See Rwelamira, supra note 43, at 170 .

92. OAU Refugee Convention, art. II(2), supra note 8.

93. These states are Comoros, Libya, and Mauritius. See States Parties to the Convention and Protocol, UNHCR, https://www.unher.org/en-us/protection/basic/ 3b73b0d63/states-parties-1951-Convention-relating-to-status-of-refugees (last visited Mar. 29, 2020).

94. African Charter on Human and Peoples' Rights, June 27, 1981, 1520 U.N.T.S. 217.

95. See Boed, supra note 83. See also A. VERDOODT, NAISSANCE ET SIGNIFICATION DE LA DECLARATION UNIVERSELLE DES DROITS DE L'HOMME 155-56 (1964). 
diminished by the UDHR, the UN Refugee Convention, or subsequent international instruments. ${ }^{96}$ Article 12, paragraph 3 of the African Charter itself recognizes that the alleged right to seek and obtain asylum in other countries is subject to the "law of those countries and international conventions." 97 This suggests the precedence of the OAU Refugee Convention and the UN Refugee Convention insofar as a State's right to grant asylum, or not, is concerned. Thus far, there has been only one case concerning asylum before the African Commission on Human and Peoples' Rights, and none as yet before the African Court on Human and Peoples' Rights. ${ }^{98}$ Subsequent African state practice suggests that the grant of asylum remains within the exclusive discretion of States. Outside the African regional refugee regime, a limited right to asylum has evolved under the European Convention on Human Rights ${ }^{99}$ for persons subject to deportation or extradition proceedings in countries that are parties to the Convention. ${ }^{100}$

96. See, e.g., OAU Refugee Convention, supra note 8; Arboleda, supra note 65.

97. African Charter, supra note 94 , art. 12(3).

98. In Organisation Mondiale Contre la Torture and Association Internationale des Juristes Démocrates v. Rwanda, the African Commission stated, in relation to Article $12(3)$, only that the article "should be read as including a general protection of all those who are subject to persecution, that they may seek refuge in another State." See African Commission on Human and Peoples' Rights, Tenth Annual Report, 27/89-46/90-49/9199/93 (Oct. 1996), https://www.refworld.org/cases,ACHPR,51b6f4374.html.

99. Council of Europe, Convention for the Protection of Human Rights and Fundamental Freedoms, Nov. 4, 1950, 213 U.N.T.S. 22.

100. See David Scott Nance, The Individual Right to Asylum Under Article 3 of the European Convention on Human Rights, 3 MICH. J. INT'L L. 477, 484-88 (1982) (discussing the emergence of a variant of an individual right to be granted asylum, albeit under limited conditions, in a series of decisions by the European Commission of Human Rights beginning in 1961. Nance traces the evolution of a doctrine of nondeportation, as a limited variant to the right to asylum, and its application by the Commission in a number of cases. The limiting conditions identified by the Commission are that "(a) the applicant is to be deported to a country known for its denial of human rights, for example where it is clear that he or she will be subjected to inhuman or degrading treatment; and (b) the circumstances relating to the applicant be "exceptional", i.e. that upon examination of the relevant fact situations, the Commission comes to the conclusion that there are "serious reasons to believe that the person concerned will be subjected, in the State to which he is to be sent, to treatment which is in violation of Article 3."). In Nance's reading, the essence of the doctrine of nondeportation under Article 3 is that it diverges from what might be expected of a full-fledged right of asylum in two senses. First, it can arise only in situations in which the individual has already entered the country in which he or she seeks asylum; second, the right depends not on the conditions from which an individual has fled, but on the anticipated treatment the individual will be subjected to if returned to the country of origin. 


\section{Explaining the Other Aspects: Burden-Sharing, Temporary Protection, and Voluntary Repatriation}

Finally, three other interrelated normative innovations in the international refugee law regime merit brief mention here. First, Article II, paragraph 4 of the OAU Refugee Convention introduced the concept of burden-sharing, described as "a very early form of responsibilitysharing." ${ }^{101}$ In my view, the notion of burden-sharing in this context should be understood to include regional resettlement of refugees, financial support, and sharing political responsibility. Article II, paragraph 4 of the OAU Refugee Convention provides that:

[W] here a Member State finds difficulty in continuing to grant asylum to refugees, such Member State may appeal directly to other Member States and through the $\mathrm{OAU}$, and such other Member States shall in the spirit of African solidarity and international cooperation take appropriate measures to lighten the burden of the Member State granting asylum. ${ }^{102}$

Notice that the language of this provision mentions "difficulty in continuing to grant asylum." This suggests a requirement that asylum should have already been granted in each individual case.

The apogee of burden-sharing occurred during the 1970s and 1980 s, with the influx of refugees from apartheid South Africa and other southern African countries still engaged in national liberation struggles, into other African countries. ${ }^{103}$ Although most of these refugees sought asylum in the neighboring independent States within the southern African region (such as Botswana, Lesotho, Swaziland, and Zambia), other States farther afield (including Tanzania in East Africa and Nigeria in West Africa) took in their share of these refugees and provided financial and material assistance as well. Because of this mass migration, following the entry into force of the OAU Refugee Convention in 1974, the OAU established the Refugees, Displaced Persons, and Humanitarian Affairs Division as a unit within the OAU General Secretariat with the responsibility of coordinating the organization's

101. Sharpe, supra note 60 , at 107.

102. OAU Refugee Convention, supra note 8, art. II(4).

103. See James Schneider, The Refugee Crisis in Southern and Central Africa, 4 GLOBAL DIALOGUE 1 (1999) (noting that as recently as the 1980s countries such as South Africa, Angola, Mozambique, and Namibia remained primary source countries for refugees), available at https://sites.tufts.edu/jha. 
policies with Member States on this and other issues. ${ }^{104}$ Thus, on paper, if not in practice, African States had agreed on an expanded approach to the application of the principles of non-refoulement and burden-sharing before other countries elsewhere. However, as has been noted by JeanFrancois Durieux and Agnès Hurwitz, in recent times, each of these possible methods of burden-sharing has since been constrained in practice by the limited resources of the African States. ${ }^{105}$

A contemporary situation that presents a challenge to the principle of burden-sharing is the refugee flows from the conflict in South Sudan, Africa's newest country, into other neighboring East African countries. As was recently acknowledged in a statement by the UNHCR, eight months after fresh violence erupted in South Sudan, a famine produced by the vicious combination of fighting and drought has been driving the world's fastest growing refugee crisis. ${ }^{106}$ Estimates of people displaced from South Sudan into the surrounding States in the last two-and-ahalf years stand at about 1.6 million, with almost half of these persons crossing into the northern part of Uganda, and the rest fleeing into Sudan, Ethiopia, Kenya, the Democratic Republic of the Congo, and the Central African Republic. ${ }^{107}$ This alarming rate of displacement not only represents an impossible burden on a poor region, which is quickly running short of resources to cope with the problem, but it also erases

104. See OAU Council of Ministers Resolution on the Bureau for the Placement and Education of African Refugees, CM/Res. 346 (XXIII) (June 6-15, 1974). See also Sharpe, supra note 11, at 71-74 (discussing the legislative history of the Bureau for the Placement and Education of African Refugees, which was integrated into the OAU General Secretariat as the Refugees, Displaced Persons and Humanitarian Affairs Division). The restructuring of the Bureau in 1974 also included formalizing the role of the OAU's Liberation Committee, which was responsible for coordinating the OAU's support for the various national liberation movements in Southern Africa, in providing humanitarian assistance to refugees fleeing the apartheid and minority-ruled colonial regimes in the region.

105. See Jean-Francois Durieux \& Agnès Hurwitz, How Many is Too Many? African and European Legal Responses to Mass Influxes of Refugees, 47 GER. Y.B. INT'L L. 105, 128-29 (2004). The issue of financial constraints as a critical factor in the demand for burdensharing and responsibility-sharing in international refugee protection was at the heart of discussions during the first-ever UN General Assembly High-Level Summit on Addressing Large Movements of Refugees and Migrants held on Sept. 19, 2016 in New York. See generally Volker Türk \& Madeline Garlick, From Burdens and Responsibilities to Opportunities: The Comprehensive Refugee Response Framework and a Global Compact on Refugees, 28 INT'L J. REFUGEE L. 656 (2016) (discussing regional responsibility-sharing, including in Africa).

106. UNHCR Press Release, South Sudan's Refugee Crisis Now the World's Fastest Growing, Uganda and Region in Critical Need of HeIp (Mar. 17, 2017).

107. Id. 
any possibility of implementing among these States the principle of burden-sharing provided for in the OAU Refugee Convention. 108

Second, there is the notion of temporary protection articulated in the OAU Refugee Convention. Article II, paragraph 5 provides that:

\begin{abstract}
"Where a refugee has not received the right to reside in any country of asylum, he may be granted temporary residence in any country of asylum in which he first presented himself as a refugee pending arrangement for his resettlement in accordance with the preceding paragraph." 109
\end{abstract}

At first reading, this provision seems to imply only temporary protection of a limited nature. ${ }^{110}$ In my view, the more correct interpretation, however, is that the provision is intended to apply to persons who have been recognized as refugees, but for one reason or another have not been granted the right of residence for any duration at all. Thus, the OAU Refugee Convention does not operate to limit State obligations towards refugees. Rather, it spreads the obligations to other States, so that when a person is recognized as a refugee and granted asylum in one African country, and is later resettled in another African country, the resettlement simply continues her refugee status in the new country. The idea here is to remedy situations in which a refugee may have been granted asylum, but not an accompanying right of residence. It is the residence in the first country that is temporary, and not the refugee status and protection itself. There is thus a close link between temporary protection and burden-sharing. But temporary protection need not mean limited protection.

The third issue concerns voluntary repatriation, which is rendered more explicitly in the OAU Refugee Convention than in the UN Refugee Convention. The explicit probibition on forced repatriation in this provision has been described as "a powerful statement of principle" and as an early expression of a principle that has since become "the

108. $I d$.

109. OAU Refugee Convention, supra note 8, art. II(5),

110. Bonaventure Rutinwa, Prima Facie Status and Refugee Protection 22 (New Issues in Refugee Research, Working Paper No. 69, 2002) (citing an unpublished study by the Centre for Refugee Research Unit, York University, Canada, The Temporary Protection of Refugees: A Solution-Oriented and Rights Regarding Approach, (1996), which concludes that "[the] debate about temporary versus permanent refugee protection has no real currency in the [Global] South, where protection has almost always been assumed to be temporary, even if it lasted for a long time. Protection has usually been provided by neighboring countries with the clear understanding that the refugees would eventually return home."). 
cornerstone of the international regime for refugee protection." ${ }^{111}$ As noted earlier, the prohibition of involuntary repatriation is, in its effect, functionally equivalent to the principle of non-refoulement.

At the same time, however, instances of forced repatriation or expulsions of refugees have occasionally punctuated intra-African political relations. In some cases, while governments have officially committed themselves to only voluntary repatriation, they have simultaneously carried out forced ejections of refugees under the pretext of security concerns, as happened in 1993 when the Kenyan government forcibly repatriated over one thousand Somali refugees from Kenyan refugee camps. ${ }^{112}$ In other cases, the ejection of refugees can be a matter of formal policy. This was seen in July 1999, when Zambia ordered the immediate deportation of all nationals of the Democratic Republic of the Congo, which included many refugees. ${ }^{113}$ Similarly, Angolan refugees in Namibia and Rwandan refugees in Zimbabwe were reclassified as "illegal immigrants" and thus subject to exclusion of refugee status, enabling refoulement and expulsion. ${ }^{114}$ This was also the justification for the forced repatriation of over five thousand Rwandan refugees from Tanzania in 2006, despite the fact that Tanzania had previously either recognized or naturalized most of these citizens. 115

On other occasions, refugees have "voluntarily" returned because of conditions created deliberately to leave them with no option but to give up their refugee status and return to their countries of origin. For example, Tanzanian refugee camps apparently denied Burundian refugees food, as did Ugandan camps harboring Sudanese refugees. ${ }^{116}$

111. See Durieux \& Hurwitz, supra note 105, at 130 . It is significant that subsequent state practice elsewhere outside Africa has followed this principle. See, e.g., Bilateral Agreement on the Voluntary Return of Refugees, Afg.-Pak., art. III, Apr. 14, 1988, 27 ILM 585.

112. See JAMES C. HATHAWAY, THE RightS of REFugEeS UNDER INTERNATIONAL LAW 283 (2005).

113. Id. at 284 .

114. Id. at 285 .

115. Earlier, in 1980 , Tanzania had naturalized about 36,000 Rwandan refugees who had been living in the country for several years, in some cases for generations. See Aderanti Adepoju, Refugees in Africa: Problems and Prospects 11 (1984), Paper presented at the Symposium on Assistance to Refugees - Alternative Viewpoints, Oxford, United Kingdom on March 27-31, 1984.

116. See HATHAWAY, supra note 112 , at $288-89$ (citing the cases of Burundian refugees and Sudanese refugees in Tanzania and Uganda, respectively, who were reported to be voluntarily repatriating but were actually leaving because of dramatic reductions in their food rations, coupled with being denied the right to earn a living through economic activity). See generally Bonaventure Rutinwa, The End of Asylum? The Changing Nature of Refugee Politics in Africa (New Issues in Refugee Research, Working Paper No. 5, 1999). More recent threats to forcibly expel refugees include those by the Kenyan government in respect of Somali refugees on account of security concerns (May, 2016) and by the 
This has led observers, such as Cristiano D'Orsi, to claim that voluntary repatriation is a principle honored more in its breach than in its observance in Africa. ${ }^{117}$ While there is some truth in this claim, which reflects a declining commitment toward asylum and refugee protection in some countries, compliance with the obligation set out in Article 5, paragraph 1) of the OAU Refugee Convention remains the rule, rather than the exception.

Although the gap between law and practice - or legal and practical protection-under the Convention in Africa is often wide, ${ }^{118}$ the OAU has had three major impacts on international legal developments and practice: the adoption in practice of the OAU refugee definition by multilateral organizations, provision of inspirational guidance in multilateral regional treaties, and the use of nonexclusive binding language. First, the principles contained in the OAU Refugee Convention have been adopted by various agencies of the UN. The UNHCR's execution of its mandate in Africa has, for example, employed refugee protection policies embedded in the UN Refugee Convention, the Refugee Protocol, and the OAU Refugee Convention. ${ }^{119}$ Significantly, the UNHCR's Executive Committee of the High Commissioner's Programme concluded that the definition of a refugee under the UN Refugee Convention should be broadened to take account of mass displacement, and suggested using the exact wording of Article I(2) of the OAU Refugee Convention (though the latter convention is not directly attributed). ${ }^{120}$ Moreover, the OAU Refugee Convention has also guided the activities of other relevant UN agencies, such as the World Health Organization and World Food Programme. ${ }^{121}$

Second, the OAU Refugee Convention has provided the inspiration for another kind of regional instrument: ${ }^{122}$ The 1984 Cartagena

Ugandan government with respect to Burundian refugees following a claim by Burundian authorities that the country was safe after months of civil unrest (Feb., 2017). Both the Kenyan and Ugandan governments subsequently retreated and neither threat was carried out.

117. See generally Cristiano d'Orsi, Sub-Saharan Africa: Is a New Special Regional Refugee Law Regime Emerging?, 68 HEWELBERG J. INT'L L. 1057 (2008) (analyzing aspects of the present refugee law regime in Sub-Saharan Africa in order to assess how the institution of asylum is legally perceived and applied).

118. See Okoth-Obbo, supra note 44, at 85; Wood, supra note 23, at 579.

119. See Sharpe, supra note 66 at 15.

120. See YASSIN EL-AYOUTY \& I WILLIAM ZARTMAN, THE OAU AFTER TWENTY YEARS 224 (1984). See also Sharpe, supra note 60, at 103.

121. See, e.g., U.N. Secretary-General, Report of the Secretary-General on Assistance to Refugees, Returnees and Displaced Persons, U.N. Doc. A/65/324 (Aug. 24, 2010).

122. See, e.g., Arboleda, supra note 39, at 194 (discussing the OAU Convention's role in expanding the meaning of 'refugee' amongst African States). Moreover, the Group of Latin American countries in the UN officially recognized the influence of the OAU Refugee 
Declaration on Refugees, which ten Latin American countries created to address the situation of refugees in the Central American region. ${ }^{123}$ As already noted, Article I, paragraph 2 of the OAU Refugee Convention expands the UN Refugee Convention definition by adding that the term refugee shall also apply to:

[Every] person who, owing to external aggression, occupation, foreign domination or events seriously disturbing public order in either part or the whole of his country of origin or nationality, is compelled to leave his [or her] place of habitual residence in order to seek refuge in another place outside his country of origin or nationality.

Article III, paragraph 3 of the Cartagena Declaration similarly states that in addition to the elements contained in the 1951 UN Refugee Convention and the 1967 Refugee Protocol, the definition or concept of a refugee recommended for use in the region is one that includes "[persons] who have fled their country because their lives, security or freedom have been threatened by generalized violence, foreign aggression, internal conflicts, massive violation of human rights or other circumstances which have seriously disturbed public order." In fact, the Cartagena Declaration's definition goes further than that of the OAU's, by specifying more elements. Although not a binding treaty, the Declaration has since been incorporated in the national law and state practice of sixteen countries. ${ }^{124}$

Convention's definition in a submission to the Working Group on Solutions and Protection of the Executive Committee of the High Commissioner's Programme in 1991. See United Nations High Comm'r for Refugees, Report of the Working Group on Solutions and Protection to the Forty-Second Session of the Executive Committee of the High Commissioner's Programme, IT 23-26 (Aug. 12, 1991).

123. The Cartagena Declaration was elaborated and adopted by delegates from the following countries: Belize, Colombia, Costa Rica, El Salvador, Guatemala, Honduras, Mexico, Nicaragua, Panama, and Venezuela. Cartagena Declaration. It was reaffirmed by the San Jose Declaration on Refugees and Displaced Persons, adopted by the Colloquium on the International Protection of Refugees in Central America, Panama, and Mexico held on Dec. 7, 1994. San Jose Declaration on Refugees and Displaced Persons, Dec. 7, 1994, https://www.refworld.org/docid/4a54bc3fd.html. The San Jose Declaration extends the scope of the application of the Cartagena Declaration to internally displaced persons.

124. These countries are Argentina, Belize, Bolivia, Brazil, Chile, Colombia, Costa Rica, Ecuador, El Salvador, Guatemala, Honduras, Mexico, Nicaragua, Paraguay, Peru, and Uruguay. See Regional Definition of Refugee (Cartagena), Table 1: Latin American Countries that Fave Frcorporated it into their National Legislation, available at https://acnur.org/fileadmin/Documentos/Proteccion/Buenas_Practicas/11261.pdf. See also 
Last, there is one remarkable feature of the OAU Refugee Convention to which commentators have not generally drawn attention: the use of nonexclusive, binding language. ${ }^{125}$ For example, the principles of asylum, non-refoulement, burden-sharing, and nondiscrimination are all broadly addressed to "OAU Member States," and not specifically or restrictively to "Signatory States," although the latter term is used in other provisions of the Convention. 126 This paper argues that the usage of these different terms was not accidental, but a deliberate choice by the drafters. This choice was likely driven by the optimistic belief at the time that all OAU Member States would, in time and as a matter of course, become parties to the OAU Refugee Convention, as a regional instrument dealing with a problem of critical significance for the African continent. The fact that today the OAU Refugee Convention has one of the highest number of parties of all OAU treaties, next only to the AU Constitutive Act and the African Charter, is a validation of the early desire of African states to expand certain aspects of existing international law to address their specific needs and problems.

South Africa embraced this desire when it acceded to the OAU Refugee Convention on December 15, 1995.127 The remainder of this discussion examines the extent to which South Africa's legislative policies, administrative practices, and judicial decision making respect the objectives and obligations enshrined not only in the OAU Refugee Convention, but also in the UN Refugee Convention, which it acceded to within a month of its accession to the former OAU Refugee Convention. ${ }^{128}$

Cathryn Costello, Article 31 of the 1951 Convention Relating to the Status of Refugees, UNHCR LEGAL AND PROTECTION POLICY ReS. SERIES, July 2017, at 11 n. 57.

125. Article 4 enshrines the general principle of equality and non-discrimination, which is a fundamental element of international human rights law, in the application of the Convention to refugees. It provides: "Member States undertake to apply the provisions of this Convention to all refugees without discrimination as to race, religion, nationality, membership of a particular social group or political opinion." OAU Refugee Convention, supra note 8 , art. 4.

126. Undoubtedly, the drafters of the OAU Refugee Convention would have been aware that the obligations set out in the treaty would only bind the parties to it. However, given the political context in which the treaty evolved, there was probably a desire that all members of the organization, including non-signatory states, embrace the new principles set out in it as a shared consensus on the protection of refugees in the new, postcolonial Africa.

127. D'Orsi, supra note 8 , at 223 n. 13.

128. Refugee Protocol, supra note 10. 


\section{REFugee Status Determination PROCEDURES UNDER SOUTH AFRICAN LAW}

In this Part, we examine the refugee status determination procedures under two periods. The first period ran from April 1994, when the new post-apartheid government was installed, and lasted until March 2000. As noted above, although the Refugees Act was signed into law during this period, on November 20, 1998, it did not come into operation until April 1, 2000. ${ }^{129}$ The second period follows the entry into force of the Refugees Act, and continues through to the present.

\section{A. Refugee Status Determination Procedure from 1994 to 2000}

Early in the first period, in mid-April 1994, the Department of Home Affairs developed guidelines for its operational officers for the refugee status determination of Mozambicans in South Africa. Within six months, by the end of September 1994, the scope and application of these administrative arrangements had been extended to all persons seeking refugee status in South Africa. ${ }^{130}$ However, the first period was marked by the fact that South Africa did not have domestic legislation for the protection of refugees and asylum seekers. It relied on its immigration law, with the Aliens Control Act as the key legislation. For the greater part of the first period, therefore, South Africa managed the emerging refugee problem in the country without a refugee regime.

Jonathan Klaaren and Christopher Sprigman have critically investigated the procedures for refugee determination status that were in force during the first period mentioned above. They have termed this administrative system as a "centralized bureaucratic model," 131 which they contrast with the system that was eventually adopted under the Refugees Act. They characterize the latter system as a "decentralized hearing-based model," which allows for individualized status determination hearings that afford the applicant, at some level, the opportunity for legal representation. ${ }^{132}$ We do not propose to reassess

129. See supra note 15.

130. See Jonathan Klaaren \& Christopher Sprigman, Refugee Status Determination Procedures in South African Law, in ADVANCING REFUGEE PROTECTION IN SOUTH AFRICA 61, 62 nn. 5-6 (Jeff Handmaker, Lee Anne de la Hunt \& Jonathan Klaaren eds., 2008).

131. Id. at 62-73 (discussing in comprehensive detail the refugee status determination procedures during the period 1994-2000, and the provisions of the Refugees Act which had just become operational but had not yet been interpreted by the courts or administrative tribunals dealing with refugee status determination claims).

132. Id. at $73-82$. 
Klaaren's and Sprigman's analysis in any detail. We generally share their position with respect to the discussion on the centralized bureaucratic procedures and administrative arrangements prior to the enactment of the Refugees Act, which we describe briefly below.

Prior to adopting its domestic refugee legislation, asylum seekers in South Africa were dealt with only in terms of the Aliens Control Act, which provided for the control of the admission of persons to, their residence in, and their departure from South Africa, but did not provide for the recognition or protection of refugees. ${ }^{133}$ Hicks has argued that the Aliens Control Act overzealously conferred power to immigration officers to find, detain, and repatriate undocumented immigrants and that this power was subsequently abused by immigration authorities by infringing upon the rights of immigrants. 134

The Aliens Control Act provided that, in the first instance, all persons who were not citizens of South Africa were aliens. ${ }^{135}$ There was a general prohibition on foreigners entering or remaining in South Africa with a view to permanent residence or temporary residence without the necessary immigration permit or temporary residence permit. ${ }^{136}$ Foreigners who had been removed from the country under a warrant in terms of sections 45,46 or 47 of the Aliens Control Act as undesirable inhabitants due to convictions for certain designated offenses or in the public interest were prohibited from reentering or remaining in South Africa. 137

As we have stated above, the Aliens Control Act did not provide for the recognition or protection of refugees. It was not long after the adoption of the final Constitution of South Africa in 1996 that the constitutionality of the Aliens Control Act was put under the spotlight by legal commentators and scholars. The legislation was regarded as a

133. The Aliens Control Act was, in its own terms, described as "Act to provide for the control of the admission of persons to, their residence in, and their departure from, the Republic; and for matters incidental therewith." None of its dispositive provisions contained any reference to asylum seekers or refugees or to the recognition and protection of the rights of asylum seekers and refugees. See Aurelia Wa Kabwe-Segatti, Reforming Immigration Policy in Post-Apartheid South Africa: From the Aliens Control Act of 1991 to the Immigration Act of 2002, in TEN YEARS OF DEMOCRATIC SOUTH AFRICA: TRANSITION ACCOMPLISHED? 171, 177 (Aurelia Wa Kabwe-Segatti, Nicolas Pejout \& Philippe Guillaume eds., 2006) (arguing that closer scrutiny reveals that the 1991 legislation was meant to tackle domestic issues rather than to be a long-term management instrument for regional migrations).

134. See Thomas F. Hicks, The Constitution, Aliens Control Act, and Xenophobia: The Struggle to Protect South Africa's Pariah-The Undocumented Immigrant, 7 IND. J. Global LEGAL STUD. 393, 408-09 (1999).

135. Aliens Control Act of $1991 \S 1$ (S. Afr.).

136. $I d . \S 23$.

137. Id. $\S 49$. 
vestige of the apartheid era, and was criticized as symbolizing the racist sentiments inherent in the past society and which, in the post-apartheid era, institutionalized the practice of favoring whites over non-whites in immigration-related issues and encouraged xenophobia. ${ }^{138}$ Klaaren and Sprigman have noted that the initial post-apartheid developments regarding refugee protection were at the level of international law, when on September 6, 1993 South Africa signed a Basic Agreement with UNHCR to govern the role of the refugee agency in the country. ${ }^{139}$ This was followed by the Tripartite Agreement between South Africa, Mozambique, and UNHCR on October 15, 1993, under which the South African government belatedly granted "group refugee status" to Mozambican nationals in South Africa. ${ }^{140}$ Following this development, the Department of Home Affairs established procedures and a bureaucratic structure, the Refugee Affairs Unit, to manage refugee status determination for all applicants apart from the Mozambican nationals. This marked the first instance in which international refugee status became formally applicable to asylum seekers in South Africa. ${ }^{141}$ Consequently, a policy designed to recognize former Mozambican refugees for purposes of repatriation became the basis of the asylum procedure until the entry into force of the Refugees Act on April 1, 2000.

Under the pre-2000 procedure, the application for asylum was made to an immigration officer who referred the application to the Refugee Affairs Standing Committee (Standing Committee). ${ }^{142}$ The Standing Committee received and considered all applications. In its determination process, it relied on the information provided by the immigration officer who interviewed the asylum seeker. ${ }^{143}$ The Standing Committee advised the applicant of the outcome of the application

138. Hicks, supra note 134 , at 394 n. 5 (citing HuM. RTS. WATCH, "ProHIBITED PERsons:" AbUSE of Undocumented Migrants, ASYLUM-SEEkERS, AND REFUGEeS IN SoUTH AFricA, at app. A6 (1998)); see also Jonathan Crush \& David A. McDonald, Introduction to Special Issue: Evaluating South African Immigration Policy After Apartheid, 48 AFR. TODAY 1, 1 (2001)).

139. Klaaren \& Sprigman, supra note 130, at 62. Under the Basic Agreement South Africa agreed to use the refugee definitions in the UN Refugee Convention and OAU Refugee Convention.

140. See Tripartite Agreement between South Africa, Mozambique, and UNHCR, art. 1(a). The objective of the Basic Agreement between South Africa and UNHCR of 1993 was to facilitate the repatriation of Mozambican refugees.

141. Klaaren \& Sprigman, supra note 130 , at 62 .

142. The Standing Committee and the Appeal Board for Refugee Affairs were established following the Basic Agreement between South Africa and UNHCR; id.

143. The Department of Home Affairs established four Regional Offices of Refugee Affairs where specially trained immigration officers conducted interviews. These offices were located in the country's four major cities: Cape Town, Durban, Johannesburg, and Pretoria. 
through an immigration officer. The Standing Committee was required to provide all asylum seekers with reasons, in writing, for any adverse decisions. ${ }^{144}$ In the event of an unsuccessful application, the applicant could appeal to the Appeal Board for Refugee Affairs (Appeal Board). ${ }^{145}$ While the decisions of the Standing Committee and the Appeal Board were pending, and while the application was being finalized, the asylum seeker was entitled to study or work in South Africa.

In Somali Association of South Africa v. Limpopo Department of Economic Development Environment and Tourism, the court held that asylum seekers in South Africa also have the right to open businesses in South Africa and that, accordingly, the State must allow asylum seekers to apply for and renew business permits and licenses. ${ }^{146}$ The Court also held that it was unlawful for the government to close permitted businesses owned by asylum seekers. ${ }^{147}$

In Kabuika $v$. Minister of Home Affairs, ${ }^{148}$ asylum seekers from Zaire (now the Democratic Republic of the Congo) sought an interim interdict that would direct the Minister of Home Affairs to allow them to remain in South Africa pending a judicial review of the decisions by the Standing Committee and the Refugee Board. ${ }^{149}$ The Court examined the findings of the Standing Committee and the Board and found, after considering reports from Amnesty International and other international bodies concerning the state of affairs in the former Zaire, that the applicants had shown, at the very least, a prima facie right to relief and that they had a well-grounded apprehension of irreparable harm should they be forced to leave South Africa. ${ }^{150}$ The Court found that the

144. Until December 1996, the Standing Committee refused to provide reasons for rejections. But in a case brought before the Cape of Good Hope Provincial Division of the High Court, an order by consent was granted which required the Standing Committee to provide reasons in writing for any adverse decision. See Pembele v. Appeal Board for Refugee Affairs (CC) (S. Afr.).

145. See supra note 143. The purpose of the Appeal Board for Refugee Affairs was to consider all appeals made against the decision of the Standing Committee for Refugee Affairs. A chairperson of the Appeal Board was appointed on Sept. 6, 1995 as its sole member. The Refugees Act of 1998 established a new Refugee Appeal Board under section 12(1). The Refugee Appeal Board consists of a chairperson and at least two other members, and its mandate is set out in section 14(1).

146. Somali Association of South Africa v. Limpopo Department of Economic Development Environment and Tourism 2015 (1) SA 151 (SCA) at para. 46(2)(a)(i) (S. Afr.). 147. Id. para. $46(\mathrm{~b})(\mathrm{b})$.

148. See generally Kabuika v. Minister of Home Affairs 1997 (4) SA 341 (C) (S. Afr.)

149. Id. at 341- J ((noting that this was an application for an order directing the respondents (the Standing Committee and the Refugee Appeal Board) to issue temporary residence permits to the applicants pending the review of certain decisions of the respondents).

150. Id. at $344 \mathrm{~J}-345 \mathrm{~A}$. 
relevant decisionmaking bodies had failed either to consider the reports or to attach adequate weight to them and also that they had misunderstood the asylum seekers' version of events regarding their movements in Zaire. ${ }^{151}$ The Court ordered the Minister of Home Affairs to allow the applicants to remain in South Africa pending final determination of the review proceedings that were instituted in respect of to the decisions of the Standing Committee and the Refugee Appeal Board. ${ }^{152}$

B. Refugee Status Determination Procedure under the Refugees Act, 1998

Since becoming operational on April 1, 2000, the Refugees Act has undergone four amendments, but only one of these has come into effect. ${ }^{153}$ None of these amendments substantively affect the procedure for refugee status determination established under the Refugees Act. The following sections describe the procedure for application for refugee status under the law as it currently stands.

The procedure for application for refugee status under the Refugees Act, read with the Refugee Regulations promulgated by the Minister of Home Affairs in terms of section 38 of the Act, ${ }^{154}$ is similar in many respects to the previous procedure under the Aliens Control Act. ${ }^{150}$ Accordingly, judicial decisions such as Kabuika v. Minister of Home Affairs ${ }^{156}$ and Baramoto and Others v. Minister of Home Affairs and Others, ${ }^{157}$ decided in 1997 and 1998, respectively, just before the enactment of the Refugees Act, have informed courts adjudicating cases concerning refugee status applications.

Baramoto involved three applicants, all former generals in the armed forces of the former Zaire, who had entered South Africa in the first half of 1997, following the fall of the government of long-time

151. Id. at $344-\mathrm{H}$.

152. Id. at $345 \mathrm{C}-\mathrm{E}$.

153. See generally infra note 197 (the four amendments made to the Refugees Act rince it became operational in 2000).

154. Regulations to the Refugees Act, GN R.366 of GG 6779 (6 Apr. 2000) (S. Afr.).

155. Refugees Act of 1998 ch. 2-3 (S. Afr.). The fundamental difference lies in the philosophical approaches underpinning the procedures under the two regimes. As noted earlier, the period prior to the Refugees Act was premised on a centralized bureaucratic model, whereas the period from 2000 onwards is predicated on the notion of a decentralized hearing-based model. See KLAAREN \& SPRIGMAN, supra note 130, at 62-82.

156. See generally Kabuika v. Minister of Home Affairs 1997 (4) SA 341 (C) (S. Afr.) (involving asylum-seekers from seeking an interim interdict to remain in South Africa while awaiting judicial review of Standing Committee and Board decisions).

157. See, e.g., Baramoto and Others v. Minister of Home Affairs and Others 1998 (5) BCLR 562 (W) (S. Afr.). 
dictator Mobutu Sese Seko. Although the generals had initially entered South Africa legally and held temporary residence permits, they were arrested when they reentered the country after they had illegally sneaked out to briefly return to the Democratic Republic of the Congo. ${ }^{158}$ The South African government changed its attitude toward the applicants, and adopted the position that their continued presence in South Africa was no longer acceptable. The applicants were denied renewal of their residence permits, and became liable for removal under section 44, paragraph 1 of the Aliens Control Act. ${ }^{159}$ The applicants launched an urgent application in which they sought, inter alia, to restrain the government from removing them from the country. They also sought an order declaring that they were refugees as contemplated in the refugee instruments binding on South Africa, and compelling the Minister of Home Affairs to issue them temporary residence permits. The Court ruled that the government was obliged to apply the law and to give effect to the international agreements binding upon it. It specifically noted that:

[if] the applicants qualify as refugees, notwithstanding the settled intention of the Government of South Africa, the applicants will be entitled to be dealt with as refugees and would remain in South Africa subject to the provisions of the OAU Convention as referred to in the affidavit deposed to by the Minister of Safety and Security. ${ }^{160}$

The Court held that while the government was entitled to take political decisions that might affect the status of the applicants, such decisions "must be taken in terms of the law or the law must be amended so that the political decisions are in conformity therewith." 161 The Court granted interim relief to the applicants and gave them ten

158. Id. at 568 .

159. Id. at 569 .

160. Id. at 575 (accepting without equivocation, the argument by the applicant's counsel that the Government of South Africa was bound by the OAU Refugee Convention, the UN Refugee Convention, and the Refugee Protocol, as well as the Constitution of South Africa, ss. 231 and 232, which respectively provide that international agreements ratified by the National Assembly and customary international law are binding on the Republic of South Africa).

161. Id. at 577. Although this was not among the factual issues in the affidavits placed before the Court, there was speculation in South African diplomatic and intelligenee circles that Mobutu's former generals were plotting to overthrow the new government of Laurent Kabila. See Lynne Duke, Ex-Mobutu Aides Arrested, WASH. PoST (Dec. 16, 1997), https://www.washingtonpost.com/archive/politics/1997/12/16/ex-mobutu-aides-arrested. 
days within which to make any application for recognition of their refugee status. ${ }^{162}$

All applications for refugee status and asylum must be made in person without delay at any one of the four Refugee Reception Offices in the country, and a Refugee Reception Officer (RRO), an official of the Department of Home Affairs, is tasked with ensuring that applications for asylum are properly completed. ${ }^{163}$ If necessary, the RRO must assist the applicant in completing the form, and may conduct an inquiry to verify the information contained in the application. ${ }^{164}$ In Kiliko $v$. Minister of Home Affairs, ${ }^{165}$ the High Court held that the Department of Home Affairs has a duty to provide adequate facilities essential for an expeditious handling of applications for asylum seeker permits. ${ }^{166}$ The RRO is required to submit applications received by him or her to an RSDO. ${ }^{167}$ Consistent with Article 31 of the UN Refugee Convention, the Refugees Act also provides that no proceedings against asylum applicants waiting on a decision and who have had the opportunity to exhaust their rights to review or appeal as well as those applicants granted asylum, may be instituted or continued in respect of their unlawful entry or presence in South Africa. ${ }^{168}$

The Supreme Court of Appeal has decided a number of cases that implicate some of the provisions in the Refugees Act and Immigration Act mentioned above. ${ }^{169}$ None of these cases reached the Constitutional Court. However, in Ruta v. Minister of Home Affairs (Ruta), ${ }^{170}$ the Court had occasion to determine two questions that had also been at issue in the previous cases. The first set of questions arise from the requirement in section 21 of the Refugees Act, which states that applications for refugee status and asylum must be made "without delay." Does a delay in submitting an application adversely affect the asylum seeker's right to apply for asylum? And what length of period constitutes a delay?

162. Baramoto and Others v. Minister of Home Affairs and Others 1998 (5) BCLR 562 (W) at 577 (S. Afr.).

163. Refugees Act 130 of $1998 \S 21$ (b) (S. Afr.). The four designated Refugee Reception Offices are located in the cities of Durban, Musina, Port Elizabeth, and Pretoria,

164. Refugees Act 130 of $1998 \S 21(2)$ (c) (S. Afr.).

165. See Kiliko v. Minister of Home Affairs 2006 (4) SA 114 (C) at para. 28 (S. Afr.).

166. See Intercape Ferreira Mainliner Ltd. v. Minister of Home Affairs 2010 (5) SA 367 (WCC) at paras. 21-24 (S. Afr.); 410 Voortrekker Rd. Prop. Holdings CC v. Minister of Home Affairs 2010 (8) BCLR 785 (WCC) at paras. 2-4 (S. Afr.).

167. See Refugees Act $\S 24$ (S. Afr.).

168. Id. § 21(4).

169. See, e.g., Abdi v. Minister of Home Affairs 2011 (3) SA 37 (SCA) (S. Afr.); Ersumo v. Minister of Home Affairs 2012 (4) SA 581 (SCA) (S. Afr.); Bula v. Minister of Home Affairs 2011 ZASCA 209 (S. Afr.); Arse v. Minister of Home Affairs 2010 (7) BCLR 640 (SCA) (S. Afr.).

170. Ruta v. Minister of Home Affairs 2018 ZACC 52 at para. 3 (S. Afr.). 
The second set of questions relate to whether an applicant's adverse immigration status in the country, such as illegal entry or commission of a crime while in South Africa, is relevant for determining refugee status.

The applicant in this case, Alex Niwubona Ruta, was a Rwandan national who had entered South Africa unlawfully in December 2014 and was, therefore, in terms of the Immigration Act, an illegal immigrant. At issue was whether a prospective asylum seeker should be allowed to apply for asylum at any time they might express an intention to do so after arriving in the country - even if they have delayed - within the terms of section 21 of the Refugees Act and whether an asylumseeker convicted of a crime committed within South Africa was barred from applying for asylum. These questions involved the interface between these twin pieces of legislation.

The RSDO had turned down Mr. Ruta's application for asylum. On review, the High Court overruled this decision, determining that he was entitled to be granted refugee status. However, on appeal, the Supreme Court of Appeal departed from its own previous decisions and overruled the High Court decision. It held that Ruta had failed to apply for asylum "without delay," as both the Refugees Act and the Immigration Act require. Additionally, it found that he was disqualified from applying for and receiving a refugee permit because he had contravened the Immigration Act by entering the country illegally and had been convicted of a crime-traffic violations-while in South Africa. ${ }^{171}$ The Constitutional Court unanimously overturned the Supreme Court of Appeal's ruling. The Court held that under the Refugees Act, delay in submitting an application does not in itself disqualify an asylum application and that the only grounds on which an application may be refused are those set out in the Refugees Act itself (discussed in the next section below). ${ }^{172}$ The Court also held that while the Immigration Act determines who is an "illegal foreigner" that is liable to deportation, the Refugees Act is the only pertinent statute in determining who may seek asylum and who is entitled to refugee status under a process managed by the RROs and adjudicated by the RSDOs. ${ }^{173}$

The Ruta decision underscores the principles discussed in Part I of this essay. First, regarding the individual right to asylum, the judgment recognizes that foreign nationals do not have the right to enter, remain

171. Id. paras. 1-6 (setting out a summary of the facts and litigation history in the High Court and Supreme Court of Appeal).

172. Id. para. 53 (stating that the Refugee Act, not the Immigration Act, is the legislation governing asylum applications); id. para. 56 (stating that delay does not function as an absolute disqualification from initiating the asylum application process).

173. See id. para. 43. 
or reside anywhere in South Africa and that no international conventions create such a right. Second, however, by enabling asylumseekers to have their status determined under the Refugees Act, in conformity with South Africa's obligations under international law, the law ensures that they can have their applications for refugee status properly considered under the process set out in the Refugees Act itself, and not to be deported summarily under the Immigration Act. In other words, they enjoy the protection of the principle of non-refoulement.

\section{(i) Asylum Seekers: "Section 22 Permit"}

Once a foreigner has made an application for asylum, the RRO must issue the applicant with an asylum seeker permit allowing him or her to sojourn in South Africa. ${ }^{174}$ This permit-also known as the "section 22 permit"-remains valid while the application to be granted refugee status is finalized. ${ }^{175}$ This allows the individual to remain legally in South Africa and move about the country freely until their hearing to determine their eligibility for refugee status. Under regulations promulgated by the Minister of Home Affairs, asylum seekers were prohibited from employment or studying, at least for the first six months of their presence in South Africa. However, in Minister of Home Affairs v. Watchenuka, ${ }^{176}$ the Supreme Court of Appeal held that the blanket prohibition violated asylum seekers' constitutional right to dignity. In so finding, the Supreme Court of Appeal stated that human dignity has no nationality because it is inherent in all people, simply because they are human. Asylum seekers are thus authorized, in general, to work or study in South Africa pending the finalization of their applications for asylum. Of course, in order to work or study, asylum-seekers must obtain the relevant work or study permits that the law requires of other non-nationals.

The section 22 permit also allows asylum seekers or immigrants to access other services, such as opening a bank account, accessing healthcare, and sending their children to school. In the recent case of Centre of Child Law v. Minister of Basic Education, ${ }^{177}$ the High Court

174. Refugees Act $\S 22$ (S. Afr.).

175. See Minister of Home Affairs v. Somali Ass'n of S. Africa E. Cape 2015 (3) SA 545 (SCA) at para. 3 (S. Afr.).

176. Minister of Home Affairs $v$. Watchenuka 2004 (4) SA 326 (SCA) at 330 (S. Afr.).

177. Ctr. of Child Law v. Minister of Basic Educ. 2019 ZAECGHC 126 at para. 135 (S. Afr.). The ruling is in line with the decision in Watchenuka (4) SA 326. The Supreme Court of Appeal has subsequently reaffirmed Watchenuka in a number of other decisions. See, e.g., Somali Ass'n of S. Africa v. Limpopo Dep't of Econ. Dev. Env't and Tourism 2014 ZASCA 143 at para. 40 (S. Afr.). 
confirmed that sections 39 and 42 of the Immigration Act do not prohibit the provision of basic education, which is guaranteed under section 29 of the Constitution of South Africa, to undocumented foreign children. Sections 39 and 42 of the Immigration Act purport to prohibit schools from providing basic education to children who are illegal foreigners, which would include children of asylum seekers not yet in possession of the section 22 permit. The ruling is thus as relevant to illegal foreigners, in general, as it is to asylum-seekers specifically.

\section{(ii) Decisions on Asylum Applications}

Although their actual performance has not often lived up to this, RSDOs are by law required to possess experience and knowledge of refugee matters. ${ }^{178}$ When considering or taking decisions on asylum applications, they are bound by the provisions of the Constitution that guarantee that "[e]veryone has the right to administrative action that is lawful, reasonable, and procedurally fair." 179 RSDOs must also ensure that the applicant fully understands the procedures, and their rights and responsibilities. The RSDO may request information or clarification from the applicant or the RRO, and may consult with a UNHCR representative as necessary.

There are four possible outcomes to an asylum application. First, the RSDO may grant asylum. Second, the application may be rejected as unfounded, in which case the applicant may appeal to the Refugee Appeals Authority (previously the Refugee Appeal Board). The Refugee Appeals Authority may set aside or substitute a decision of the RSDO to reject an asylum application. ${ }^{180}$ Third, the RSDO may reject an application as manifestly unfounded, abusive, or fraudulent. ${ }^{181}$ The record of applications rejected as manifestly unfounded, abusive or fraudulent must be submitted to the Standing Committee. ${ }^{182}$ Fourth, the RSDO may refer any question of law to the Standing Committee before making a final determination. In that case, the Standing

178. Ref Refugees Act $\$ 8(2)$ (b) (S. Afr.).

179. Id. § 24(2); S. AFR. CONST., $1996 \S 33(1)$.

180. Refugees Act $\S \S 24(3)$ (c), 26(2) (S. Afr.).

181. Abusive applications are those made with the purpose of defeating or evading criminal or civil proceedings or repeated applications made without any substantial change in the applicant's personal circumstances or in his or her country of origin; id. § 1(i). Fraudulent applications are those made by applicants who know the facts contained in the application to false and such facts are intended to materially affect the outcome of the application; id. $\S 1$ (xi). Manifestly unfounded applications are those made on grounds other than the recognized grounds for granting asylum; id. § 1(xii).

182. Id. § 24(4)(b); see Tripartite Agreement, supra note 140 (describing the establishment of the Starding Committee). 
Committee must refer the application back to the RSDO within fourteen days, with such directives as may be necessary, and oblige the RSDO to decide on the application in terms of the directives. Determinations should generally be adjudicated within 180 days of the filing of a completed asylum application with the RRO. ${ }^{183}$

The leading case on the substance and process for asylum applications is Tantoush v. Refugee Appeal Board. In this case, the High Court set aside the rejection of Tantoush's application for asylum by the Refugee Appeal Board, and substituted its own decision by declaring that he was a refugee and entitled to asylum. ${ }^{184}$ In doing so, it held that the appropriate standard to be applied is one of "a well-founded fear of persecution," used by the US Supreme Court in Immigration and Naturalization Service v. Cardoza-Fonseca, ${ }^{185}$ and not, as the Refugee Appeal Board had held, that an applicant was required to prove "a real risk of persecution on a balance of probabilities." 186

Applicants have the right to appeal to the High Court for a review of the decisions that have rejected their refugee status applications, and in many cases they have done so unopposed by the Department of Home Affairs. ${ }^{187}$ At the same time, RROs have an obligation to renew the asylum seeker's permit until the High Court review is finalized. ${ }^{188}$

\section{Objectives and Other Aspects of the Refugees Act, 1998}

The Refugees Act was enacted to give effect to the OAU Refugee Convention and the UN Refugee Convention within South Africa, ${ }^{189}$

183. GN R.366 of GG $21075 \S 3(1)$ (S. Afr.).

184. Tantoush v. Refugee Appeal Bd. 2008 (1) SA 232 (T) at 233-34 (S. Afr.). Cf. Arse v. Minister of Home Affairs 2010 (7) BCLR 640 (SCA) at paras. 15-17 (S. Afr.).

185. See INS v. Cardoza-Fonseca, 480 U.S. 421,440 (1987).

186. The essential difference here is thus between "a reasonable fear of persecution" as against "a clear probability of persecution."

187. See, e.g., Tekalign v. Minister of Home Affairs 2018 (3) All SA 23 (ECP) at para.1 (S. Afr.). See also Ngwenya $v$. Minister of Home Affairs 2017 ZAGPJHC 222 at para. 1 (S. Afr.); O.N. v. Chairperson of the Standing Comm. for Refugee Affairs 2017 ZAWCHC 57 at para. 11 (S. Afr.); Mubala v. Chairperson of the Standing Comm. for Refugee Affairs 2013 ZAWCHC 208 at para. 20 (S. Afr.).

188. Saidi v. Minister of Home Affairs 2018 (4) SA 333 (CC) (S. Afr.).

189. The Refugees Act in its own terms describes its objective as "Act to give effect within the Republic of South Africa to relevant international legal instruments, principles and standards relating to [refugees]." Furthermore, the Preamble states: "WHEREAS the Republic of South Africa has acceded to the 1951 Convention Relating to the Status of Refugees, the 1967 Protocol Relating to the Status of Refugees and the 1969 Organization of African Unity Convention Governing the Specific Aspects of Refugee Problems in Africa as well as other human rights instruments [BE IT THEREFORE ENACTED] by the Parliament of the Republic of South Africa, as [follows]." 
provide for the reception of asylum seekers, regulate applications for and recognition of refugee status, and provide for the rights and obligations flowing from such status. These objectives have been reaffirmed in a number of cases, including Watchenuka $v$. Minister of Home Affairs, ${ }^{190}$ Minister of Home Affairs v. Watchenuka, ${ }^{191}$ Kiliko $v$. Minister of Home Affairs, ${ }^{192}$ Abdi v. Minister of Home Affairs; ${ }^{193}$ and Scalabrini Centre v. Minister of Home Affairs. ${ }^{194}$ The Refugees Act expressly stipulates that it must be interpreted and applied with due regard to the OAU Refugee Convention, the UN Refugee Convention, the Refugee Protocol, the UDHR, and any other relevant human rights treaty to which South Africa is a party, ${ }^{195}$ a point that was underscored by some legal commentators shortly after it became effective. ${ }^{196}$ Since its enactment, the Refugees Act has been amended four times: in 2008, 2011, 2015, and 2017. ${ }^{197}$ Except for the 2015 amendment, none of the amendments have come into operation. The key change in the 2015 amendment is that a Refugee Appeals Authority has replaced the Refugee Appeal Board, and the media and general public are allowed to access the Authority's hearings.

As pointed out earlier, the definition of a refugee and the criteria for granting refugee status, provided for in the Refugees Act, mirror those in the UN Refugee Convention, the Refugee Protocol, and the OAU Refugee Convention. ${ }^{198}$ Consistent with Article I, paragraph 2 of the OAU Refugee Convention, the Refugees Act also provides that a person may qualify for refugee status if, owing to external aggression, occupation, foreign domination, or events seriously disturbing or disrupting public order, in either a part or the whole of his or her country of origin or nationality, he or she is compelled to leave his or her

190. Watchenuka v. Minister of Home Affairs 2003 (1) SA 619 (SCA) at 621 F-I (S. Afr.).

191. Minister of Home Affairs v. Watchenuka 2004 (4) SA 326 (SCA) at para. 2 (S. Afr.).

192. Kiliko v. Minister of Home Affairs 2006 (4) SA 114 (C) at para. 25 (S. Afr.).

193. Abdi v Minister of Home Affairs 2011 (3) SA 37 (SCA) at para. 22 (S. Afr.).

194. Scalabrini Ctr., Cape Town v. Minister of Home Affairs 2017 (4) All SA (SCA) at 16 para. 35 (S. Afr.).

195. See Refugees Act $\S 6$ (S. Afr.).

196. See generally Margaret Beukes, 'Economic Refugees:' South African Reality and International Refugee Law, 27 S. AFR. Y.B. INT'L L. 206 (2002); Simla Budhu, The Extent of Municipal Obligation Towards Refugees in South Africa, 26 S. AFR. Y.B. INT'L L. 246 (2001); Frankie Jenkins, Coming to South Africa: An Overview of the Application for Asylum and an Introduction to the Refugees Act, 24 S. AFR. Y.B. INT'L L. 182 (1999); (providing background information and an introduction to the Refugees Act).

197. Respectively, Refugees Amendment Act 33 of 2008 (S. Afr.), not yet in force; Refugees Amendment Act 12 of 2011(S. Afr.), not yet in force; Refugees Amendment Act 10 of 2015 (S. Afr.), assented to on Sept. 23, 2015, came into operation on Sept. 27, 2015; Refugees Amendment Act 11 of 2017 (S. Afr.), not yet in force.

198. See Refugees Act $\S 3(a)$ (S. Afr.). 
place of habitual residence in order to seek refuge elsewhere. 199 Another unique feature of the Refugees Act is that it defines "social group" broadly, to include a group of persons of a particular gender, sexual orientation, disability, class, or caste. ${ }^{200}$

\section{Non-refoulement and Access to South African Territory}

In this paper, we have noted the wide consensus that the principle of non-refoulement obliges states to refrain from forcibly returning a refugee to a state where they are likely to suffer persecution or danger to life or freedom. ${ }^{201}$ This principle is generally regarded as having crystallized into a rule of customary international law. ${ }^{202}$ The prohibition on refoulement is an exception to the international law rule that grants every sovereign state the inherent power to forbid the entrance of aliens into its territory, or to admit them only in such cases and upon such conditions as it may see fit to prescribe. ${ }^{203}$

The principle of non-refoulement also operates to ensure that asylum-seekers may not be turned away at the border. The UN Refugee Convention protects asylum-seekers who have crossed into the territory of a state without authorization. ${ }^{204}$ Both the UN General Assembly's

199. Id. § 3(b).

200. The act also provides that dependents of a person granted refugee status are also to be regarded as refugees. Id. $\S 1$ (xxi).

201. See generally D'Orsi, supra note 91; see Lauterpacht \& Bethlehem, supra note 70 . As it relates to South Africa, see the discussion by Fatima Khan. Fatima Khan, The Principle of Non-refoulement, in Khan \& Schreier, supra note 12, at 3-19.

202. C. Costello \& M. Foster, Non-refoulement as Custom and Jus Cogens? Putting the Prohibition to the Test, 46 NETH. Y.B. INT'L L. 273, 274 (2015); Saidi v. Minister of Home Affairs 2018 (7) BCLR 856 (CC) at para. 32 (S. Afr.); Kabuika v. Minister of Home Affairs 1997 (4) SA 341 (C) at 343 (S. Afr.). The term "customary international law" is used here in the sense in which it is commonly understood or defined by international lawyers, namely as consisting of rules derived from the habitual conduct of states or a general practice accepted as law, and existing independently of treaty law.

203. See Ekiu v. United States, 142 U.S. 651, 662 (1892). See also Fong Yue Ting v. United States, 149 U.S. 698 (1893); Chinese Exclusion Case, 130 U.S. 581 (1889); Xu $v$. Minister van Binnelandse Sake 1995 (1) BCLR 62 (T) (S. Afr.); Naidenov v. Minister of Home Affairs 1995 (7) BCLR 891 (T); Parekh v Minister of Home Affairs 1996 (2) SA 710 (D). But see Foulds v. Minister of Home Affairs 1996 (4) SA 137 (W); Tettey v. Minister of Home Affairs 1999 (3) SA 715 (D); Jonathan Klaaren, So far, not so Good: An Analysis of Immigration Decisions Under the Interim Constitution, 12 S. AFR. J. ON HUM. RTS. 605 (1996); R. Pretorius, Protecting the Rights of Aliens in South Africa: International and Constitutional Issues, 21 S. AFR. Y.B. IN'?'L L. 130 (1996); R.J. Purshotam, The Right of Aliens and Migrants to Administrative Justice and $a$ Brief Look at the Abuse Suffered by Them in South Africa, 116 S. AFR. L.J. 32 (1999); J. Nafziger, The General Admission of Aliens Under International Law, 77 AM. J. OF INT'L L. 804 (1983).

204. UN Refugee Convention, supra note 10, art. 33(1). 
Declaration on Territorial Asylum and the OAU Refugee Convention declare that asylum seekers should not face "measures such as rejection at the frontier." 205 South Africa acknowledges the obligation to allow asylum seekers entry into its territory in terms of the Refugees Act, which expressly states that no person seeking asylum may be refused entry. ${ }^{206}$ Furthermore, South Africa makes two concessions for asylum seekers, which exempts them from its ordinarily applicable standards for migration. These concessions are immunity from prosecution for unlawful entry into or presence within the country, and protection from treatment as illegal immigrants. ${ }^{207}$

First, under the Refugees Act, asylum seekers are permitted to enter South Africa without the need for a passport or a valid visa. ${ }^{208}$ Moreover, the Immigration Act provides that immigration officials may "issue an asylum transit visa to a person who at a port of entry claims to be an asylum-seeker, valid for a period of five days only, to travel to the nearest Refugee Reception Office in order to apply for asylum." 209 The Immigration Act, and the regulations promulgated under it, bestow no authority on border officials to conduct interviews relating to the validity or otherwise of a claim made by an asylum seeker, but they may issue an asylum transit visa to an asylum seeker who applies "in person at a port of entry." 210 The issuance of such a visa does not imply the validity of the asylum claim itself. Second, the Refugees Act protects asylum seekers who enter South Africa irregularly. ${ }^{211}$ Refugees are protected from arrest, detention, and deportation as illegal immigrants under section 2 of the Refugees Act. Under the provisions of this section, no person may be "expelled, extradited or returned to any other country" if that person may be subjected to persecution on account of their race, religion, nationality, political opinion or membership of a particular social group, or if such person's physical safety or freedom would be threatened on account of external aggression, occupation, foreign domination, or other events that seriously disturb public order.

205. G.A. Res. 2312(XXII) (Dec. 14, 1967); OAU Refugee Convention, supra note 8, art. II(3).

206. Refugees Act $\S 2$ (S. Afr.); see Abdi v. Minister of Home Affairs 2011 (5) BCLR 529 (SCA) at para. 22.

207. Refugees Act $\S 21(4)$ (S. Afr.);

208. This is the logical implication of the express prohibition of denial of entry to persons arriving at the port of entry and seeking asylum; in most cases, especially in situations of mass flight, refugees do not travel with visas.

209. See generally Immigration Regulations 2002, GN R.22 of GG 10199 (22 May 2014) (setting out the procedure for an asylum transit visa for asylum-seekers).

210. Immigration Regulations 2002, Regulation 22(1), GN R.413 of GG 37679 (22 May 2014).

211. Refugees Act § 21(4) (S. Afr.). 
The Constitutional Court reaffirmed the principle of nonrefoulement in Gavrić $v$. Refugee Status Determination Officer. ${ }^{212}$ Briefly, the facts of the case as set out in the judgment are that Dobrosav Gavric fled his native country of Serbia because he feared for his life following the assassination in 2000 of Zeljo Ražnatović, commonly known as Arkan. Ražnatović was a commander of a paramilitary unit closely aligned with the government of Slobodan Milošević during the conflict in the former Yugoslavia in the 1990s. Gavrić was present at Ražnatović's assassination and became the main suspect for the murder. He fled illegally to South Africa in 2007 under a false name and passport. In the meantime, on October 9, 2008, he was convicted in absentia of the murders of Ražnatović and his two bodyguards. He was initially sentenced to a term of 30 years' imprisonment, but this was later increased on appeal to 35 years' imprisonment by the Serbian Supreme Court. In 2012, Gavrić applied for refugee status in South Africa on the grounds that he was falsely believed to be a member of the political group responsible for the commander's death, and had a well-founded fear of being killed by the deceased's supporters. The RSDO refused to grant refugee status under section 4(1)(b) of the Refugees Act, which provides that a person does not qualify for refugee status if there is reason to believe that he or she committed a crime which is not of a political nature and which, if committed in South Africa, would be punishable by imprisonment.

Gavric applied to the High Court (Western Cape Division) for a review of the RSDO's decision rejecting his application for asylum. The presiding judge dismissed the application and also denied him leave to appeal to the full bench of the High Court. The Supreme Court of Appeal also refused him leave to appeal, after which he sought leave to appeal from the Constitutional Court. The Constitutional Court held, inter alia, that non-refoulement applies even to those who have been excluded from refugee status under section 4(1)(b) of the Refugees Act. The Constitutional Court recalled that in two previous cases, it had concluded that:

The State, or any official in the employ of the State, does not have the power to extradite or deport or in any way remove a person from South Africa to a retentionist State, who, to its knowledge, if deported or extradited to

212. Gavrić v. Refugee Status Determination Officer, Cape Town and Others 2019 (1) BCLR 1 (CC) at paras. 26-27, 38 (S. Afr.). 
such a State, will face the real risk of the imposition and execution of the death penalty. ${ }^{213}$

In Gavrić, the Constitutional Court addressed the possibility that an excluded applicant could be returned to a country where there was a risk that they may be killed or persecuted. 214 The Court also emphasized that, given the catastrophic consequences that can result if an asylum application is wrongly rejected, and that many applicants are unrepresented, vulnerable, and lacking in the necessary language and legal skills, RSDOs must provide adequate reasons for rejections. Similarly, it concluded that procedural fairness demands that any information relied upon by the authorities must be provided to the asylum seeker so that they have a fair and meaningful opportunity to make representations and to know what factors may weigh against their interests. ${ }^{215}$ The Court concluded that Gavric had been denied procedural fairness. We return to this case in more detail below (in Part III.C.2) in relation to the question of a political crime for purposes of exclusion from refugee status.

The Constitutional Court has again reaffirmed the principle of nonrefoulement even more strongly in another decision after Gavrić. In the more recent case of Ruta v. Minister of Home Affairs, ${ }^{216}$ the Court demonstrated a keen appreciation of the burden that refugees impose on the State, and the particular burdens the Department of Home Affairs and its officials are obliged to bear. But the Court was again unequivocal in upholding both the constitutional principles underlying the Refugees Act and the Immigration Act, and the plain meaning of the language in those statutes. The ratio of the judgment is that "[all] asylum-seekers are protected by the principle of non-refoulement, and the protection applies as long as the claim to refugee status has not been finally rejected after a proper procedure." ${ }^{217}$ And that section 2 of the Refugees Act "embodies all these principles. It goes further than the 1951 Convention. Its more generous wording is derived from our own

213. Id. at paras. 26-27 nn. 17, 22 (recalling Minister of Home Affairs v. Tsebe 2012 (10) BCLR 1017 (CC), and Mohamed v. President of the Republic of S. Afr. (Soc'y for the Abolition of the Death Penalty in S. Afr. and Another Intervening) 2001 (7) BCLR 685 (CC)).

214. Since Gavrić had been sentenced to a term of imprisonment, and not the death penalty, he claimed that he feared being killed or persecuted by supporters of Arkan, the commander for whose murder he had been convicted. See supra, note 212, Gaurić v. Refugee Status Determination Officer, Cape Town 2018 (38) ZACC 1 (CC) at para. 2 (S. Afr.).

215. Id. ๆๆ $72 \cdot 75,78-81$.

216. Ruta v. Minister of Home Affairs 2019 (3) BCLR 383 (CC) at para. 58 (S. Afr.).

217. Id. I 29. 
continent - the Organisation of African Unity Convention Governing the Specific Aspects of Refugee Status [sic] in Africa." 218

It is worth quoting the Constitutional Court's judgment on this point in extenso. After recalling the provision in section 2 of the Refugees Act, which encapsulates the principle of non-refoulement, the Court states:

This is a remarkable provision. Perhaps it is unprecedented in the history of our country's enactments. It places the prohibition it enacts above any contrary provision of the Refugees Act itself - but also places its provisions above anything in any other statute or legal provision. That is a powerful decree. Practically it does two things. It enacts a prohibition. But it also expresses a principle: that of non-refoulement, the concept that one fleeing persecution or threats to "his or her life, physical safety or freedom" should not be made to return to the country inflicting it.

It is a noble principle - one our country, for deep-going reasons springing from persecution of its own people, has emphatically embraced. The provenance of section 2 of the Refugees Act lies in the Universal Declaration of Human Rights (Universal Declaration), which guarantees "the right to seek and to enjoy in other countries asylum from persecution". The year in which the Universal Declaration was adopted is of anguished significance to our country, for in 1948 the apartheid government came to power. Its mission was to formalise and systematise, with often vindictive cruelty, existing racial subordination, humiliation and exclusion. From then, as apartheid became more vicious and obdurate, our country began to produce a rich flood of its own refugees from persecution, impelled to take shelter in all parts of the world, but especially in other parts of Africa. That history looms tellingly over any understanding we seek to reach of the Refugees Act.

The principle of protecting refugees from persecution was elaborated three years after the Universal Declaration, in article 33 of the Convention Relating to 
the Status of Refugees of 1951 (1951 Convention). This gave substance to article 14 of the Universal Declaration. The 1951 Convention defined "refugees", while codifying non-refoulement. South Africa as a constitutional democracy became a State Party to the 1951 Convention and its 1967 Protocol when it acceded to both of them on January 12, 1996 - which it did without reservation. In doing so, South Africa embraced the principle of non-refoulement as it has developed since 1951. The principle has been a cornerstone of the international law regime on refugees. It has also become a deeply-lodged part of customary international law and [is] part of international human rights law. As refugees put agonising pressure on national authorities and on national ideologies in Europe, North America, and elsewhere, the response to these principles of African countries, including our own, is of profound importance. ${ }^{219}$

This decision is the most recent pronouncement on, and definitive interpretation of, the principle of non-refoulement by the Constitutional Court, that is at the highest judicial level.

\section{Treatment of Asylum Seekers and Refugees: \\ Detention, Exclusion and Cessation}

\section{(i) Detention of Failed Asylum Seekers}

The detention of failed asylum seekers has been an officially sanctioned policy in South Africa since the end of apartheid. Such persons are usually held in camps that have been established in various parts of the country for undocumented migrants pending their repatriation. ${ }^{220}$ But as discussed below, the problem is that in

219. Id. ๆ⿻ 24-26.

220. The best known of these is the Lindela Repatriation Centre (Lindela) located in the small town of Krugersdorp, west of Johannesburg. Established by the Department of Home Affairs in 1995 as a holding facility for foreigners awaiting deportation, and not a refugee camp as such, it has become infamous as a camp where failed asylum-seekers have routinely been held, sometimes unlawfully. Unsurprisingly, it has attracted much criticism from human rights and refugee rights advocates. See RONI AMIT, BREAKING THE LAW, BREAKING THE BANK: THE COST OF HOME AFFaIRS' ILlegGal DETENTION PRACTICES 51-57 (2012). See generally Corey Johnson, Failed Asylum Seekers in South Africa: Policy and Practice, 1 AFR. HUM. MOBLITY REV. 201 (2015) (discussing the issues surrounding 
implementing the policy, officials of the Department of Home Affairs and officers of the police force have detained and deported illegal aliens and asylum seekers alike, probably due to a combination of ineptitude and deliberate disregard of the law. Indeed, some commentators have noted that the issue of immigration detention illustrates the tension between mixed migration and refugee protection, and how law enforcement officials and other government functionaries often fail to distinguish between asylum seekers, illegal immigrants, and criminals. ${ }^{221}$ While the use of immigration detention is fairly common around the world, empirical evidence from South Africa reveals a high incidence of its use at the expense of asylum seekers. ${ }^{222}$ The cases also suggest a less coordinated, more arbitrary, and more poorly defined response to managing immigration and asylum applications among the concerned government departments and officials. ${ }^{223}$

The Immigration Act and the Refugees Act establish the legal framework of immigration detention in South Africa. The Immigration Act provides that a person subject to deportation or detention as an illegal foreigner "[may] at any time request any officer attending to him or her that his or her detention for the purpose of deportation be confirmed by warrant of a Court, which, if not issued within 48 hours of such request, shall cause the immediate release of such foreigner." 224 Section 34(1)(d) of the Immigration Act further states that the foreigner concerned "[may] not be held in detention for longer than 30 calendar days without a warrant of a Court which on good and reasonable grounds may extend such detention for an adequate period not exceeding 90 calendar days." Section 4(1)(e) provides that such foreigner "[shall] be held in detention in compliance with minimum prescribed standards protecting his or her dignity and relevant human rights." 225

As discussed earlier, the principle of non-refoulement prohibits the detention of asylum seekers for purposes of returning them to the territory from which they have fled due to a well-founded fear of persecution. Therefore, any deportation of an asylum seeker, who is authorized by the Department of Home Affairs before their status determination, is a violation of international law. However, the Refugees Act contains provisions that allow for the detention and

the lack of implementation of the refugee protection framework and analyzing South Africa's failed policies to address failed asylum seekers).

221. See Lucy Kiama \& Dennis Likule, Detention in Kenya: Risks for Refugees and Asylum Seekers, 44 FORCED MigRation REV. 34, 35 (2013).

222. See AMIT, supra note 220.

223. See Theresa Alfaro-Velcamp \& Mark Shaw, Please go Home and Build Africa: Criminalising Im migrants in South Africa, 42 J. SOUTHERN AFR. STUD. 983, 994 (2016).

224. Immigration Act 13 of $2002 \S 34(1)$ (b) (S. Afr.). Emphasis in the original.

225. Id. $\S 34(1)(\mathrm{e})$. Emphasis in the original. 
subsequent deportation of asylum-seekers. First, section 22(6) provides that "[the] Minister may at any time withdraw an asylum-seeker permit if: (a) the applicant contravenes any conditions endorses on that permit; (b) the application has been found to be manifestly unfounded, abusive or fraudulent." Secondly, sections 23 and 29 complete this legal framework. Section 23 states that:

If the Minister has withdrawn an asylum seeker permit in terms of section 22(6), he or she may, subject to section 29, cause the holder to be arrested and detained pending the finalisation of the application for asylum, in the manner and place determined by him or her with due regard to human dignity.

And section 29 provides that:

No person may be detained in terms of this Act for a longer period than is reasonable and justifiable and any detention exceeding 30 days may be reviewed immediately by a judge of the High Court of the provincial division in whose area of jurisdiction the person is detained, designated by the Judge President of that division for that purpose and such detention must be reviewed in this manner immediately after the expiry of every subsequent period of 30 days.

Thus, when considering the detention of asylum seekers and refugees, courts are assisted as much by decisions concerning the detention of foreigners under the Aliens Control Act and the Immigration Act as by the Refugees Act. ${ }^{226}$ The major difference between the Immigration Act and the Refugee Act is that under the latter, the asylum seeker can be detained only in terms of an order of the minister, and such detentions must be reviewed every thirty days by a judge of the High Court in the provincial division in whose area of jurisdiction the person is detained, designated by the Judge President of that division for that purpose. 227 In the meantime, pending a final status determination, the detained asylum seeker cannot be "removed from the Republic" (i.e. deported) except on grounds of national security

226. See, e.g., Minister of Home Affairs v. Rahim 2016 (3) SA 218 (CC), (6) BCLR 780 (S. Afr.); Aruforse v. Minister of Home Affairs 2010 (6) SA 579 (GSJ) (S. Afr.); Ulde v. Minister of Home Affairs 2009 (4) SA 522 (SCA) (S. Afr.).

227. Immigration Act 13 of $2002 \S 29(1)$ (S. Afr.). 
or public order; and such removal may only be ordered by the minister "with due regard for the rights set out in section 33 of the Constitution and the rights of the refugee in terms of international law." 228 Yet based on their interviews with security officials and immigrant and refugee rights campaigners, Theresa Alfaro-Velcamp and Mark Shaw have confirmed that the police unlawfully detained immigrants for more than forty-eight hours, and that some immigrants with expired asylum seeker permits were being held in police stations in Cape Town. ${ }^{229}$ Amit has similarly reported systematic abuses by officials of the Department of Home Affairs, which she describes as "a government department that routinely violates its constitutional duties and its legislative obligations under both the Refugees Act and Immigration Act," and "actions display[s] a general contempt for the legal process, [fails] to implement court orders, and continues to act in direct in contravention of judicial rulings." 230

These accounts confirm the decision of the Supreme Court of Appeal in Rahim v. Minister of Home Affairs, ${ }^{231}$ which ruled that fifteen illegal foreigners had been unlawfully detained by the Department of Home Affairs. Likewise, in Arse v. Minister of Home Affairs (Arse), ${ }^{232}$ the High Court ruled in favor of an asylum seeker from Ethiopia who had failed to obtain an asylum- seeker permit because the lines of applicants in the Port Elizabeth Refugee Reception Office were too long. ${ }^{233} \mathrm{He}$ was arrested as an illegal foreigner and spent a week at a police station before being transferred to Lindela Repatriation Centre, pending deportation. ${ }^{234}$ The Court ruled that Arse's detention had extended for more than 30 days; and that the detention of an asylum-seeker for the purpose of deporting him or her would violate section 2 of the Refugees

228. Id. $\S 28(1)$, (2). Section 33 of the Constitution of South Africa provides that everyone has the right to administrative action that is lawful, reasonable, and procedurally fair; and that everyone whose rights have been adversely affected by administrative action has the right to be given written reasons. See S. AFR. CONST., 1996, $\S 33(1)$ and (2), supra note 14 .

229. See Alfaro-Velcamp \& Shaw, supra note 223, at 995.

230. See AMT, supra note 220, at 7,51-57 (discussing violations of the law inside Lindela by the department of Home Affairs).

231. See Rahim v. Minister of Home Affairs 2015 (4) SA 433 (SCA) (S. Afr.). The case was appealed to the Constitutional Court, which ruled on February 16, 2016, that the Director-General of the Department of Home Affairs was required to apply his or her mind to what places are appropriate for the detention of illegal foreigners. Absent a determination having been made, the respondents were detained unlawfully and thus to be awarded damages. See Minister of Home Affairs v. Rahim 2016 (3) SA 218 (CC) at paras. 2, 11 (S. Afr.).

232. Arse v. Minister of Home Affairs 2012 (4) SA 544 (SCA) at para. 1 (S. Afr.).

233. Id. ๆ 2 .

234. Id. ๆๆ $2,8$. 
Act (enshrining the principle of non-refoulement). Accordingly, the Court ordered the Department of Home Affairs to reissue Arse with an asylum-seeker permit. 235

Arse also reconfirmed that the failure, by an asylum seeker, to obtain a section 22 permit does not provide per se justification for detention. Amit reiterates that the Supreme Court of Appeal repeated the characterization of this practice as illegal, and recalls the Court's declaration that officials of the Department of Home Affairs "have a duty to ensure that intending applicants for refugee status are given every reasonable opportunity to file an application with the relevant [Refugee Reception Office]."236

The facts in Ersumo v. Minister of Home Affairs, ${ }^{237}$ adjudicated two years after Arse, were similar. The case also involved an Ethiopian asylum seeker arrested as an illegal foreigner and detained for not having a section 22 permit. He had tried to obtain his asylum seeker permit, but he too gave up due to delays caused by long lines of applicants at the RRO. Citing its earlier decision in Bula v. Minister of Home Affairs (Bula), ${ }^{238}$ the Court noted that when an illegal foreign national indicates an intention to apply for asylum, the protection afforded by the Refugees Act applied to such a person. Like the applicants in Bula, Ersumo had communicated his intention to the authorities even while he was in detention at Lindela, and was thus entitled to the benefit of the rights afforded by the Refugees Act and Immigration Regulation 2, paragraph 2 to the Immigration Act (on issuance of permits). The Court ordered the Department of Home Affairs to issue an asylum transit permit to Ersumo, valid for fourteen days, and to set down an expedited hearing for him. ${ }^{239}$

The most recent case concerning, in part, asylum seeker permits in South Africa is AI and Others v. Director of Asylum Management: Department of Home Affairs. ${ }^{240}$ Three undocumented foreign nationals from Burundi made an urgent application to the High Court to compel the respondents, the Department of Home Affairs and others, to provide

235. Id. ๆ 22 .

236. See AMTT, supra note 220 , at 31 (stating that several asylum-seekers detain at Lindela were denied access to asylum process and were sent there after indicating their intention to apply for asylum).

237. See Ersumo v. Minister of Home Affairs 2012 (4) SA 581 (SCA) (S. Afr.). Cf. Tafira v. Ngozwane 2006 ZAGPHC 136 (S. Afr.), with Dawood v. Minister of Home Affairs 2000 SA FLII 1 (CC) (S. Afr.) (earlier cases).

238. Bula v. Minister of Home Affairs 2011 ZASCA 209; 2012 (4) SA 560 (SCA) (S. Afr.).

239. Ersumo v. Minister of Home Affairs 2012 (4) SA 581 (SCA) at paras. 17-18, 21, 23 (S. Afr.).

240. See AI and Others v. Dir. of Asylum Mgmt.: Dep't of Home Affairs 2019 SA FLII 1 (HC) (S. Afr.). 
them with section 22 permits, pending final determination of their application for refugee status. ${ }^{241}$ The facts were that the applicants arrived in South Africa from Burundi between 2006 and 2012 and applied for asylum in terms of the Refugees Act. Their applications were rejected in 2014 as being manifestly unfounded. Subsequent to the rejection of their applications, and especially in 2015, widespread political violence broke out in Burundi causing hundreds of thousands of Burundians to flee the country. Perceived opponents of the government who remained in Burundi were allegedly subjected to oppression, torture, rape, and sexual violence. The applicants argued that this rise in political violence rendered a return to Burundi unsafe, and that this change in circumstances warranted a new application for asylum. The Director of Asylum Seeker Management argued, however, that a failed asylum-seeker who had not departed South Africa after his or her application had been rejected must be deported. The applicants counterargued that the Department of Home Affairs effectively closed the door on them by refusing to accept and consider their applications. They further argued that without the section twenty-two permits, they remained undocumented, vulnerable, unable to secure accommodation or obtain jobs to provide for themselves and their families, and that they could at any time be arrested, detained, and/or deported.

The Court relied on the Ruta decision, in which that court found that delay was not a basis to exclude the applicant from making an asylum application. ${ }^{242}$ Judge Myburgh found the delay on the part of the three applicants in filing new applications, because the Department of Home Affairs officials refused to accept and consider their applications, was factually similar to Ruta. Unsurprisingly, he followed the Constitutional Court's ruling in Ruta that the Immigration Act does not trump the Refugees Act to provide a justification for the deportation of an asylum-seeker whose application had not been definitively determined. ${ }^{243}$ Judge Myburgh concluded that the applicants had a well-founded apprehension of harm and that they had a clear right to the relief they sought in their main application: namely, to be afforded the opportunity to make new applications. He ordered the Department of Home Affairs, in the meantime, to issue them with the section 22 permits. $^{244}$

The cases discussed above all reaffirm the two principles of international refugee law discussed earlier. First, there is no individual right to asylum that an asylum seeker can assert against a State:

241. Id. ๆ 1.

242. Ruta v. Minister of Home Affairs 2018 ZACC 52 at para. 56 (S. Afr.).

243. Id. at 19 \% 36.

244. Id. at 20 ๆ 39. 
the grant of asylum remains a matter of sovereign choice. Second, however, under both the UN Refugee Convention and OAU Refugee Convention, States have an obligation to not return a person to the country of origin from which they have fled due to a well-founded fear of persecution and to allow him or her to access the asylum application processes.

\section{(ii) Exclusion from Refugee Status}

The Refugees Act excludes certain persons from qualifying for refugee status. These include: persons whom there is reason to believe have committed a crime against peace, a war crime; a crime against humanity; or a crime which is not of a political nature and which, if committed in South Africa, would be punishable by imprisonment. 245 Similarly, persons who are guilty of acts contrary to the objectives and principles of the UN or the OAU (or, presumably, now the AU) are excluded from consideration for refugee status. ${ }^{246} \mathrm{~A}$ person who enjoys the protection of any other state in which they have taken residence will also fail to qualify as a refugee. ${ }^{247}$ Section 4 (1)(a) draws from similarlyworded provisions in the UN Refugee Convention and the OAU Refugee Convention. ${ }^{248}$

The relevance of section 4(1)(a) has been an issue in several cases, including Gavrić and Ruta. It has also arisen in the protracted case of Faustin Nyamwasa, a former colleague of Rwandan president Paul Kagame. Nyamwasa held a prominent position in the Rwandan government, but fled to South Africa where he was granted asylum in $2010 .{ }^{249} \mathrm{He}$ was granted refugee status despite allegations by human rights groups-and some foreign governments ${ }^{250}$ - that he had been involved in the commission of war crimes and crimes against humanity between 1994 and 1998. In 2014, the High Court ruled that Nyamwasa

245. Refugees Act $\S 4(1)(b)$ (S. Afr.); see Tantoush v. Refugee Appeal Board 2008 (1) SA $232(\mathrm{~T})$ at paras. 109-24 (S. Afr.).

246. Refugees Act $\S 4(1)(c)$ (S. Afr.) (although this provision has not been amended, this should be understood to mean the AU).

247. Id. § 4(1)(d). See, e.g., Abdi v. Sec'y of State for the Home Dep't 1996 (1) All ER 641; $R v$. Sec'y of State for the Home Dep't, Ex parte Canbolat 1998 [1] All ER 161.

248. G.A. Res. 2198 (XXI) art. 1.F, UN Refugee Convention (Dec. 16, 1967); Organization of African Unity Refugee Convention art. I(4)(f)-(g), June 20, 1974.

249. Consortium for Refugees and Migrants in S. Afr. v. President of the Republic of $S$. Afr. 2014 (SAFLII) 1 ZAGPPHC at para. 3 (S. Afr.).

250. See Cases-Extradition from South Africa: Case of Kayumba Nyamwasa, 13 Y.B. INT’L HUMANTTARIAN L. 611, 611 (M.N. Schmidt, L. Arimatsu \& T. MacCormack eds., 2010). 
had been correctly granted refugee status. ${ }^{251}$ However, on May 25, 2017, when it was set to hear an appeal by the Consortium for Refugees and Migrants in South Africa (CormSA) against the High Court decision, the Supreme Court of Appeal formalized an agreement between CormSA and several government respondents to set aside the government's decision granting Nyamwasa refugee status. The government was given 180 days to reconsider and make a final decision on Nyamwasa's refugee status. ${ }^{252}$ South Africa has maintained his refugee status and resisted demands to extradite him to Rwanda. ${ }^{253}$

\section{(iii) Cessation of Refugee Status}

Under section 5(1) of the Refugees Act, a person recognized as a refugee ceases to qualify as such in five situations. First, if they voluntarily re-avail themselves of the protection of their country of nationality. Second, if they reacquire their nationality, after they had lost it by some voluntary and formal act. Third, in terms of section 5 of the Citizenship Act No. 88 of 1995 (as amended in 2010), if they become a citizen of South Africa by naturalization, or acquire the nationality of some other country and enjoy the protection of the country of their new nationality. Fourth, if they voluntarily reestablish themselves in the country from which they originally fled. Fifth, when the circumstances in connection with which they were recognized as a refugee ceases to exist and no other circumstances arise that justify their continued recognition as a refugee. Of these five scenarios, the most common is the acquisition of South African nationality by naturalization. The last

251. See Cases-Extradition from South Africa: Case of Kayumba Nyamwasa, id. para. 26.

252. See Kyle Cowan, Former Rwandan General Nyamwasa's Refugee Status Set Aside, SOWETANLIVE, (May 25, 2017), https://www.sowetanlive.co.za/2017-05-25-formerrwandan-general-nyamwasas-refugee-status-set-aside/. The South African government regards General Faustin Nyamwasa as a political exile and a target of several attempted assassinations since 2010. In his affidavit in Ruta $v$ Minister of Home Affairs, Alex Ruta claimed that he was an intelligence agent who had been sent to South Africa to kill opponents of President Kagame, including Nyamwasa. See Geoffrey York, Another Rwandan Assassination Plot Exposed, GLOBE \& MAIL (Dec. 22, 2017), https://www.theglobeandmail.com/news/world/ruling-by-south-african-court-exposesdetails-of-latest-rwandan-assassinationplot/article37417017.

253. See Khadija Patel, Rwanda's General Nyamwasa and the Politics of Granting Refugee Status in South Africa, DAILY MAVERICK (Oct. 30, 2012), http://dailymaverick.co.za/article/2012-10-31-rwandas-general-nyamwasa-and-the-politicsof-granting-refugee-status-in-sa; see also $S A$ rejects Rwanda bid to extradite officer, REUTERS (Nov. 23, 2011), http://www.iol.co.za/news/africa/sa-rejects-rwanda-bid-toextradite-officer-1185009. 
scenario, however, provided the justification for the cessation of refugee status of Angolan refugees in South Africa in 2013.

Angola went through a devastating civil war from 1975 to 2002.254 An estimated over one-and-a-half million people died during the twentyseven-year civil war due to fighting, malnutrition, disease, and deliberate political executions; over four million people were displaced internally, and about six hundred thousand became refugees, mostly in the neighbouring countries of Botswana, the Democratic Republic of the Congo, South Africa, Namibia, and Zambia. ${ }^{255}$ When the civil war ended in 2002, more than 457,000 were still living in these countries, with Zambia alone hosting more than 225,000 refugees. ${ }^{256}$ Following the end of the war, many of these refugees were repatriated to Angola with the assistance of the UNHCR. ${ }^{257}$ In 2011, the UNHCR declared that conditions in Angola had improved and that it was safe for refugees to return home. ${ }^{258}$ This was done in terms of the provisions on "ceased circumstances" of the UN Refugee Convention. 259

In May 2013, upon the advice of the UNHCR and pursuant to section 5(1) of the Refugees Act, South Africa formally declared the cessation of refugee status for all Angolan refugees. Angolans thus

\footnotetext{
254. The war erupted after the country's declaration of independence in 1975 . Initially it involved three parties fighting over control of the country: the Popular Movement for the Liberation of Angola (MPLA), the National Union for the Total Independence of Angola (UNITA), and the National Liberation Front of Angola (FNLA). However, the FNLA was decisively defeated by the MPLA in 1976. Thereafter, the civil war continued between the MPLA, who had taken control of most of the country and formed the internationally recognized government, and UNITA, regarded by most countries as a rebel group supported militarily by the apartheid government in South Africa.

255. See THE REPATRIATION OF ANGOLAN REFUGEES AND INTERNALLY DisPLACED PERSONS, CFR (Nov. 19, 2002), www.cfr.org/report/repatriation-angolan-refugeesinternally-displaced-persons.html; see also Sergio Carciotto, Angolan Refugees in South Africa: Alternatives to Permanent Repatriation?, 2 AFR. HuM. MOBILITY REV. 362, 369-70 (2016).

256. Jonathan Crush \& Abel Chikanda, Forced Migration in Southern Africa, in THE OXFORD HANDBOOK OF REFUGEE AND FORCED MIGRATION STUDIES 554, 560 (Elena Fiddian-Oasmiyeh, Gil Loescher, Katy Long \& Nando Sigona eds., 2014).

257. See Manuel Cristovao Simao, Repatriation to Angola Officially Ends After 410,000 Go Home, UNHCR (Mar. 26, 2007), http://www.unhcr.org/4607b7d24.html.

258. United Nations High Comm'r for Refugees, Implementation of the Comprehensive Strategy for the Angolan Refugee Situation, including UNHCR's Recommendations on the Applicability of the "Ceased Circumstances" Cessation Clauses, at 2 (Jan. 15, 2012).

259. See UN Refugee Convention, supra note 10, art. 1.C(5), ("This Convention shall cease to apply to any person falling under section $A$ if: . . . [he] can no longer, because the circumstances in connection with which he as recognized as a refugee have ceased to exist, continue to refuse to avail himself of the protection of the country of his nationality."). This language is reproduced verbatim in the OAU Refugee Convention, art. I(4).
} 
became the first refugees in South Africa to have their status ceased. According to Sergio Carciotto, the declaration had two effects:

[Firstly], the South African government agreed with the UNHCR recommendation that Angola was no longer a country producing genuine refugees. Secondly, this allowed the Department of Home Affairs to find durable solutions for those individuals whose refugee status could be reversed by the Standing Committee on Refugee Affairs. ${ }^{260}$

The cessation was intended to apply to refugees that fled Angola during the period from 1961, when the war of independence from Portugal commenced, to 2002, when the civil war conclusively ended with the signing of the Luena Memorandum of Understanding on April 4, 2002 between the Government of Angola and UNITA. ${ }^{261}$ By the end of 2012, there were reported to be 16,529 Angolan nationals in South Africa, of whom 3,100 had refugee status. ${ }^{262}$ Several options were offered to the refugees under the cessation arrangement. First, the UNHCR and the South African and Angolan governments would assist those who opted for voluntary repatriation to Angola. Second, those who wished to remain in South Africa were issued with a two-year temporary visa, subject to a December 15, 2013, cut-off date, provided they obtained a national passport from the Angolan authorities. Third, Angolan refugees who chose to retain their refugee status could apply for an exemption from the cessation regime as permitted under section 5(2) of the Refugees Act and the UNHCR Guidelines on Exemption Procedures in Respect of Cessation Declaration. ${ }^{263}$ Finally, refugees who

260. Carciotto, supra note 255, at 371 (citation omitted).

261. Permanent Rep. of Angola to the U.N., Letter dated April 25, 2002 from the Permanent Rep. of Angola to the United Nations addressed to the President of the Security Council, U.N. Doc. S/2002/483 (Apr. 26, 2002) (including a copy of the memorandum of understanding between Angola and UNITA).

262. Carciotto, supra note 255, at 372 (citing information released by the Department of Home Affairs during a meeting held with the Angolan community in Cape Town, South Africa, on Jun. 16, 2012).

263. Section 5 (Legal Basis for Exemption"), para. 20 states that: "There are two categories of persons for whom general cessation does not apply, and whose applications for exemption need not be considered, namely: those who continue to have a well-founded fear of persecution; and those who have compelling reasons arising out of previous persecution for refusing to avail themselves of the protection of their country of origin." Para. 21 goes on to provide that it is immaterial whether refugee status was accorded on the basis of the 1951 Convention or an extended definition (i.e. under Article I(2) of the OAU Refugee Convention). See Guidelines on Exemption Procedures in Respect of 
opted for local integration-considered one of the "durable solutions" along with repatriation and resettlement in a third country-had their refugee status withdrawn. ${ }^{264}$ Local integration assumes that refugees voluntarily choose to remain in their country of asylum, with full legal rights, and find a solution to their plight in that country. Ideally, although not necessarily, this involves the acquisition of citizenship. ${ }^{265}$

The circumstances for cessation of refugee status contemplated in section 5(1) of the Refugees Act have been significantly expanded in the most recent iteration of the Regulations to the Refugees Act promulgated by the Minister of Home Affairs on December 27, 2019.266 Article 4(1)(a) of the Regulations sets out an extensive list of the circumstances under which a refugee loses his or her refugee status as follows:

The circumstances as contemplated in section $5(1)(a)$ of the Act in terms of which a person may be deemed to have re-availed himself or herself of origin, nationality or residence shall, amongst others, relate to where such a person voluntarily-

(a) seeks consular services at any diplomatic mission representing his or her country of origin or nationality;

(b) applies for any assistance or official document, such as a travel document or citizenship related document at any diplomatic mission representing his or her country of origin or nationality whether in the Republic or any other country;

Cessation Declaration, UNHCR (Dec. 11 2011), https://www.refworld.org/pdfid/ 4eef5c3a2.pdf.

264. Refugee status may be withdrawn in terms of section 5(3) of the Refugees Act and Regulation 17 of the Refugees Regulations (providing that when the Standing Committee on Refugee Affairs intends withdrawing status from a refugee, it must give the refugee written notice of its intention to do so, including reasons thereof, and must invite written representations from the refugee within thirty days; and that it no representations are made or if the representations do not persuade the committee otherwise, it may withdraw the refugee's status).

265. Jonathan Crisp, Local Integration and Local Settlement of Refugees: A Conceptual and Historical Analysis, NEW IssUES IN REFUGEE RES. 3 (UNHCR Working Paper No. 102).

266. See Refugees Act, 1998 (Act No. 130 of 1998), Refugees Regulations; Republic of South Africa, Government Gazette, No. 42932, Proclamation No. R. 1707, Dec. 27, 2019. The Regulations became effective on Jan. 1, 2020. 
(c) avails himself or herself of any assistance of any State official or State institution associated with or in his or her country of origin or nationality;

(d) presents himself or herself on the premises of any diplomatic mission representing his or her country of origin or nationality in the Republic or any other country;

(e) travels abroad other than with a refugee travel document issued in terms of section 31 of the Act;

(f) applies for and receives any benefit afforded to citizens of his or her country of nationality;

(g) stands for political office or votes in any election in respect of his or her country of nationality, without the approval of the Minister;

(h) whether through a port of entry of or irregularly enters the territory of his or her country of origin or nationality or countries where he or she previously resided prior to entering the Republic to apply for asylum or takes measures or prepares to do so;

(i) participates in any political campaign or activity related to his or her country of origin or nationality whilst in the Republic without the permission of the Minister; or

(j) travels abroad in violation of the conditions endorsed on his or her refugee travel document.

These expanded circumstances potentially impact the legal protections under both the OAU Refugee Convention and UN Refugee Convention in a number of respects. For example, the ban on participation in "any political campaign or activity" related to his or her country of origin or nationality has different implications from the prohibition of subversive activities under the OAU Refugee Convention. ${ }^{267}$ Political activity is not, of course, synonymous with

267. See OAU Convention on Refugees, supra note 8, art. III. Article III provides: "1. Every refugee has duties to the country in which he finds himself, which require in 
subversive activity. Moreover, under the new regulations, a refugee can be deported for getting involved in South African politics (Article 4(2)). But "participation in political activity" is a nebulous term that has not been defined in the regulations. Would a refugee's presence at a South African political party's public meeting or campaign rally be construed as such participation? Similarly, characterizing a refugee who seeks consular assistance at any diplomatic mission of his or her country of origin, nationality or residence as "re-availing himself or herself of the protection of his or her home country" is too broad and vague. Effectively, this would mean that a refugee who seeks consular assistance, for example to obtain documents to prove educational qualifications or marriage in his or her home country, loses his or her refugee status. A refugee who loses his or her refugee status under these circumstances automatically becomes an illegal foreigner at a stroke in terms of the provisions of the Immigration Act and will be liable to deportation. Some aspects of the new regulations-in particular those mentioned above-will undoubtedly weaken South Africa's commitment to the protection of the rights of refugees under its domestic legislation and the two refugee conventions.

\section{JUDICIAL INTERPRETATION OF THE OAU REFUGEE CONVENTION DEFINITION}

\section{A. Definition of a Refugee under South African Law}

The definition of a refugee in the Refugees Act incorporates both the UN Refugee Convention definition and the OAU Refugee Convention definition. Section 3 of the Act provides as follows:

Subject to Chapter 3 , a person qualifies for refugee status for the purposes of this Act if that person-

(a) owing to a well-founded fear of being persecuted by reason of his or her race, tribe, religion, nationality, political opinion or membership of a particular social group, is outside the country of his or her nationality and is unable or unwilling to avail himself or herself of

particular that he conforms with its laws and regulations as well as measures taken for the maintenance of public order. He shall also abstain from any subversive activities against any Member State of the OAU; 2. Signatory States undertake to prohibit refugees residing in their respective territories from attacking any Member State of the OAU, by any activity likely to cause tension between Member States, and in particular by use of arms, through the press or by radio." Id. 
the protection of that country, or, not having a nationality and being outside the country of his or her former habitual residence is unable or, owing to such fear, unwilling to return to it; or

(b) owing to external aggression, occupation, foreign domination or events seriously disturbing or disrupting public order in either a part or the whole of his or her country of origin or nationality, is compelled to leave his or her place of habitual residence in order to seek refuge elsewhere; or

(c) is a dependant of a person contemplated in paragraph (a) or (b).

The expanded definition in the OAU Refugee Convention is captured in section $3(\mathrm{~b})$ of the Act, which provides an independent and sufficient basis for the grant of refugee status so that individuals granted refugee status under this subsection acquire the same rights and responsibilities under the Act as those under subsections (a) and (c). Tamara Wood has noted that two changes characterize the definition incorporated in the South African Refugees Act: "[F]irst, the words 'or disrupting' have been inserted into the phrase 'events seriously disturbing public order'; and second, the final clause has been changed from requiring a person to seek refuge 'outside his or her country of origin' to merely requiring that he or she seek refuge 'elsewhere." 268 The drafting history of the Act does not establish whether these changes were deliberate efforts to alter the wording of the OAU Refugee Convention or merely accidental. But, as Wood also points out, these modifications do not undermine the protection envisaged under the OAU Refugee Convention. On the contrary, she argues that:

[E]ven if the alterations could be argued to affect the scope of the refugee definition, they would make it more, rather than less, expansive - by adding to the kind of events that give rise to refugee protection and allowing an individual to seek asylum without having left his or her country of origin. ${ }^{269}$

268. Wood, supra note 23 , at 562-63.

269. Fd. at 563 . 
In any case, the Refugees Amendment Act of 2008 removed these changes; however, this act is not yet in force.

\section{B. Burden and Standard of Proof and Consequences of Refugee Status}

It is important to note, before turning to the elements of refugee status identified in the OAU Refugee Convention and UN Refugee Convention, the approach adopted by South African courts regarding the standard and onus of proving refugee status. Three South African High Court decisions-Tantoush v. Refugee Appeal Board, ${ }^{270}$ Fang $v$. Refugee Appeal Board, ${ }^{271}$ and Van Garderen NO v. The Refugee Appeal Board ${ }^{272}$-have declared an applicant seeking refugee status is required to prove only a reasonable possibility of persecution. In Tantoush $v$. Refugee Appeal Board, the Court held that "the normal onus in civil proceedings is inappropriate in refugee cases. The inquiry has an inquisitorial element. The burden is mitigated by a lower standard of proof and a liberal application of the benefit of doubt principle." 273

As noted earlier, an applicant who is recognized as a refugee is thereby entitled to the rights established for refugees under the Refugees Act, the Constitution of South Africa, and other relevant domestic legislation, in particular the Aliens Control Act and Immigration Act. ${ }^{274}$ In a number of cases regarding the rights of nonnationals, the Constitutional Court has reaffirmed that asylum-seekers are entitled to most, if not all, of the same rights as refugees and permanent residents. The Constitutional Court has emphasized that the Constitution provides full legal protection to refugees to enjoy all the rights enshrined in the Bill of Rights (ss. 7-37) except for those limited to citizens. ${ }^{275}$ In Lawyers for Human Rights $v$. Minister of Home Affairs, the Constitutional Court held that "[the] very fabric of our society and the values embodied in our Constitution could be demeaned if the freedom and dignity of illegal foreigners are violated in the process of preserving our national integrity." ${ }^{276}$ Although this dictum is related to "illegal foreigners," it is just as applicable, if not more so, to foreigners

270. Tantoush v. Refugee Appeal Bd. 2008 (1) SA 232 (T) at 269 (S. Afr.).

271. Fang $v$. Refugee Appeal Bd. 2007 (2) SA 447 (T) (S. Afr.).

272. Van Garderen NO v. The Refugee Appeal Bd. (unreported decision 30720/2006 of June 19, 2007) (S. Afr.).

273. Tantoush 2008 (1) SA 323 (T) at para. 97 (S. Afr.) (citing Fang 2007 (2) SA 447 (T)). But see Kumah v. Minister of Home Affairs 2018 (2) SA 510 (GJ) at para. 29 (S. Afr.). These decisions referred to the UNHCR HANDBOOK, supra note 46, ๆ 196, 197.

274. Refugees Act 130 of $1998 \S 27$ (S. Afr.).

275. See S. AFR. CoNST., $1996 \S \S 7-37$.

276. 2004 (7) BCLR 775 (CC) at para. 20 (S. Afr.). 
that are legally on South African territory, such as permanent residents and refugees.

In Minister of Home Affairs v. Watchenuka, ${ }^{277}$ a case decided in the previous year, the Supreme Court of Appeal declared unconstitutional a prohibition against working and studying for asylum-seekers who do not yet have refugee status. The Court found that South Africa's international obligations, including the UN Refugee Convention, the OAU Refugee Convention, and the UDHR, "are governed by the Refugees Act No 130 of 1998."278 It held that "[human] dignity has no nationality. It is inherent in all people citizens and non-citizens alike-simply because they are human. And while that person happens to be in this country-for whatever reason-it must be respected, and is protected, by [section 10 of] the Bill of Rights." 279 The government is obliged to ensure that there is no gap between this legal protection and the practical protection afforded to refugees and asylum-seekers.

\section{Interpretation of the Expanded Refugee Definition in the OAU Refugee Convention}

\section{Events Seriously Disturbing Public Order}

The OAU Refugee Convention expands refugee protection, as noted earlier, to cover persons who are compelled to leave their homes "owing to external aggression, occupation, foreign domination or events seriously disturbing public order." 280 Various commentators have argued that the scope of this provision is unclear, particularly as it relates to "events seriously disturbing public order." 281 There has been limited published research on the actual implementation of the expanded OAU Refugee Convention definition in South Africa. ${ }^{282}$ The existing academic literature and the findings and accounts by refugee practitioners and activists share the conclusion that, in practice, Courts

277. 2004 (1) All SA 21 (SCA) at para. 20 (S. Afr.).

278. Id. ๆ 2.

279. Id. ๆ 25 .

280. OAU Convention on Refugees, supra note 8, art. I(2),

281. See, e.g., Schreier, supra note 23, at 61; Tamara Wood, Fragile States and International Protection Under the 1969 African Refugee Convention, 43 FoRCED MigRATION REV. 17, 19 (2013). See generally Okoth-Obbo, supra note 44; Sharpe, supra note 11 (evaluating the OAU's refugee definition).

282. See Amit, supra note 23; Schreier, supra note 281; Wood, supra note 23; Kaajal Ramjathan-Keogh, Country Report: Refugee Status Determination in South Africa, Paper presented at Refugee Status Determination and Rights in Southern and East Africa Regional Workshop, Kampala, Uganda (Nov. 16-17, 2010) (available at https://www.rsc.ox.ac.uk/files/files-1/dp-rsd-south-africa-2010.pdf). 
and officials fail to apply the expanded definition even in cases where the applicants base their claims on the existence of the type of generalized harm in their home countries arising from situations the expanded refugee definition intended to cover: war, internal conflict, violence, insecurity, etc. 283

Among the few studies on the subject, Amit's analysis of 324 decisions rejecting asylum claims is one of the most instructive. ${ }^{284}$ Among other issues, Amit has given particular attention to issues of implicit bias, a lack of understanding and misapplication of international and domestic refugee law, and incompetence and corruption among government officials concerned with processing these applications. Some of these findings and observations bear reproducing here. Amit found that government officials based many of the status determination decisions on errors of law:

RSDOs failed to properly apply several aspects of refugee law, including the key concept of persecution, as well as the well-founded fear and credibility elements. Moreover, few RSDOs correctly understood or utilized section 3(b) of the Refugees Act. Finally, many RSDOs demanded a more rigorous standard of proof than that required by refugee law, despite domestic court rulings to the contrary. ${ }^{285}$

Later in the same study, Amit returns to the theme of misapprehension and misapplication of the law in status determination cases. It is worth quoting her in extenso:

RSDOs routinely misapplied the core concepts of international refugee law. However, they also erroneously applied elements of domestic refugee law. Section 3(b) of South Africa's Refugees Act incorporates a provision from the OAU refugee convention that grants refugee status to individuals who have been compelled to leave their place of habitual residence "owing to external aggression, occupation, foreign domination or events seriously disturbing or disrupting public order in either a part or the whole of his or her country of origin or nationality".

283. Wood, supra note 23, at 564. See, e.g., Somali Ass'n of S. Afr. v. Refugee Appeal Bd. 2019 ZAGPPHC at 19 para 33.

284. See Amit, supra note 23, at 461.

285. Id. at 464 (citations omitted). 
RSDOs seemed largely ignorant of this provision. In fact, they often cited British case law stating exactly the opposite proposition, that fleeing the instability of civil war does not qualify an individual for asylum ... . [The] differential impact criterion is a requirement of section 3 (a) alone. The Section 3(b) provision, by contrast, is distinguished by the fact that eligibility rests solely on the presence of general conditions of instability and does not require an individualized assessment revealing a differential impact. Yet, RSDOs frequently and mistakenly based their rejections on the lack of individual persecution without considering whether the individual had a claim based on Section 3(b). Many of these decisions acknowledged that the individual was fleeing political instability, but only analyzed the claim under the Section 3(a) criteria of individual persecution . $\ldots$. $^{286}$

Amit is quite categorical in her conclusion about the failures of South Africa's asylum policy and the effects of the interaction between immigration policy and refugee protection. She states that South Africa's refugee policy: "[has] become a mechanism of immigration control, at great cost to genuine asylum seekers, who are unable to avail themselves of the rights provided to them under refugee law," and " $[\mathrm{b}] \mathrm{y}$ failing to fulfil its core protective purpose, South Africa's refugee system has become superfluous, operating instead as a regulatory mechanism for economic migrants." 287

Aside from wars or generalized harm, it is possible to interpret "events seriously disturbing public order" to include people fleeing nondiscriminatory deprivations of their human rights resulting from the complete socio-economic breakdown or State-State failure or collapse. However, South Africa has chosen not to accept such an interpretation of the definition. South Africa has seen a significant influx of Zimbabwean nationals fleeing into the country over the last decade or so. Yet applications for refugee status made by Zimbabweans claiming refuge from this situation have been almost universally rejected. ${ }^{288}$

286. $I d$. at 473 .

287. Id. at 487-88.

288. See Jonathan Crush et al., South Africa Case Study: The Double Crisis MASS MIGRATION FROM ZIMBABWE AND XENOPHOBIC VIOLENCE IN SOUTH AFRICA 11, 18 (2017) (drawing upon the UNHCR Population Statistics Database (2016), the authors note that out of 587,520 asylum applications by Zimbabweans covering the period 2003 to 2015, 
South African authorities mostly consider these applicants to be "economic migrants" fleeing the economic meltdown in their country, and not "political refugees" or "forced migrants". Thus, in Chihomba $v$. Chairperson: Refugee Appeal Board, the Court held that "[t]he principle of non-refoulement addresses bona fide Applicants for asylum and is incapable to cover economic migrants who enter South Africa to benefit financially. The political situation in Zimbabwe has settled down over the years and most Zimbabwean Nationals who travel to South Africa do so for economic reasons." 289 The Court concluded that the relative stability of law and order in the country meant that the applicant's case fell outside the scope of the OAU Refugee Convention. The applicant had adduced evidence of his long years of political involvement with the major opposition party, the Movement for Democratic Change, and climate of fear and political violence that followed the country's disputed elections of 2008, after which he left for South Africa. The Court held that, by his own account, the applicant came to South Africa to seek employment and, among other things, to assist his mother with securing anti-retroviral medicines that she was denied in Zimbabwe. More pointedly, the Court did not accept that he had a well-founded fear of persecution, noting:

It does not appear from the application why the Applicant still, after more than 6 years, requires protection. Nothing appears from the application why he is unable to re-avail himself to his country of origin so long after he feared persecution shortly before the 2008 National General Elections. On the probabilities the circumstances which gave rise to the Applicant's fears have longed ceased. The fact that his mother was deprived of anti-retroviral medication does not give rise to " $a$ well-founded fear of being persecuted", envisaged in Section 3(a) of the Act. 290

Wood has reviewed the practice of some States in the implementation of the OAU Refugee Convention and its role in protecting persons fleeing fragile States in the context of the Convention's expanded definition of a refugee. She concludes that:

only $153,924(26 \%)$ were adjudicated, of which 1,292 (less than $1 \%$ ) were granted refugee status).

289. Chihomba v. Chairperson: Refugee Appeal Bd. 2015 ZAGPPHC 444 at 29 paras. 31.4-32.

290. Id. 31.1.31.3. 
While the ... examples do not provide a comprehensive assessment of the implementation of the 1969 Convention or its role in protecting persons fleeing fragile States across the whole of Africa, they are suggestive of both of the potential and the limitations of the Convention in responding to displacement from fragile States. In particular, they suggest that States may be more willing to apply the 1969 Convention to persons in situations where the perceived cause of displacement is the existence of armed conflict and a breakdown in law and order. Where persons flee the many other symptoms of State fragility-including poor governance, food insecurity and lack of access to basic services-such application is less straightforward. ${ }^{291}$

The approach taken in Chihomba was based on its characterization of the asylum-seeker's country of origin, Zimbabwe, as neither in a fragile state nor in a continuing situation of armed conflict or generalized violence. This contrasts with the position taken in Harerimana $v$. Chairperson of the Refugee Appeals Board and Others. ${ }^{292}$ Here, the court found the asylum seeker who had fled Burundi and applied for asylum on arrival in South Africa was entitled to refugee status. ${ }^{293}$ It noted Burundi was still a fragile country that was witnessing the emergence of violent political banditry and that the applicant had been denied refugee status because the RSDO erroneously assessed his application on the basis of section 3(a) of the Refugees Act ("[owing] to a well-founded fear of persecution") when the applicant based his case on section 3(b) ("[events] seriously disturbing or disrupting public order). Significantly, Davis J. cited with approval Amit's conclusions quoted in extenso above. ${ }^{294}$

The misconstruction of section $3(\mathrm{~b})$ by the RSDOs is compounded by the fact that it also remains unclear whether the term "events seriously disturbing public order" extends to natural disasters, as has been asserted by some commentators. ${ }^{295}$ In Rahim $v$. The Minister of Home

291. See Wood, supra note 281 , at 18.

292. Harerimana v. Chairperson of the Refugee Appeal Bd. 2014 (5) SA 550 (WCC).

293. Id. ๆ 43 .

294. Id. I 41 .

295. The contention that "events seriously disturbing public order" extends to natural disasters has been asserted by some commentators. See, e.g., G. NALDI, THE ORGANIZATION OF AFRICAN UNITY: AN ANALYSIS OF ITS ROLE 83 (2d ed. 1999). 
Affairs, the Supreme Court of Appeal dismissed a claim to refugee status based on flooding. 296

\section{Political Opinion}

There is no authoritative definition of the term "political opinion," neither under the UN Refugee Convention nor the OAU Refugee Convention, nor under international law more generally. ${ }^{297}$ Political opinion can be understood in the broad sense to include "any opinion on any matter in which the machinery of State, government, society or policy may be engaged."298 The Michigan Guidelines on Risk for Reasons of Political Opinion have described "political opinion" as "[an] opinion about the nature, policies, or practices of a State or of an entity that has the capacity, legitimately or otherwise, to exercise societal power or authority." ${ }^{299}$ A number of domestic decisions in Canada, New Zealand, and the United States have also developed the meaning of "political opinion." ${ }^{300}$ In INS v. Elias-Zacarias, ${ }^{301}$ the US Supreme Court held that a refusal by Elias-Zacarias to take sides with any political faction in Guatemala was not an affirmative expression of a political opinion. Accordingly, Elias-Zacarias's claim that he would be persecuted on his return to Guatemala on the basis of political opinion failed because of his inability to adduce evidence that he either supported the government or the guerrilla movement. The Court found that he had failed to show a political motive for his refusal to undergo military service, and that he had not shown that the guerrillas threatened him because of his political opinion. ${ }^{302}$ Courts in the United States have

296. Rahim v. The Minister of Home Affairs 2015 (92) ZASCA (SCA) at para. 26 (S. Afr.). 297. See generally Colloquium on Challenges in International Refugee Law, The Michigan Guidelines on Risk for Reasons of Political Opinion, 37 MICH. J. INT'L L. 234 (2016) (discussing various considerations relevant to the meaning of the term "political opinion"). See also C. Dauvergne, Toward a New Framework for Understanding Political Opinion, $37 \mathrm{MICH}$. J. INT'L L. 243 (2016) (defining the meaning of "political opinion" generally).

298. See UNHCR HANDBook, supra note 47, ๆ 51. See also Canada (Att'y Gen.) v. Ward, [1993] 2 S.C.R. 689 (Can.); GoODWIN-GILL \& MCADAM, supra note 79, at 49.

299. See Colloquium on Challenges in International Refugee Law, supra note 298, at $234,236$.

300. See, e.g., Canada (Att'y Gen.) v. Ward, [1993] 2 S.C.R. 689 (Can.); Gutierrez Gomez v. Sec'y of State for the Home Dep't [T. Admtivos.] [Administrative Tribunals] novembre 24, 2000, 1 WLR 549 (Colom.); Refugee Appeal No. 76044 (2008) NZAR 619 (N.Z); Refugee Appeal No. 76339 (2010) NZAR 386 (N.Z.).

301. Elias-Zacarias, 502 U.S. at 483.

302. Id. at 583 (stating that "Elias-Zacarias still has to establish that the record also compels the conclusion that he has a 'well-founded fear' that the guerrillas will persecute 
generally concluded that imputed political opinion remains a viable ground for a successful claim to asylum based on political opinion even after the Supreme Court's ruling in this case. ${ }^{303}$

Conflictingly, courts in Canada have held that political opinion may be imputed to an individual by his or her government or other agent of persecution. ${ }^{304}$ In Ricardo Andizes Inzunza Orellana v. M.E.I., the Federal Court of Appeal held that "[it] should not be whether the Board considers that the applicant has engaged in political activities, but whether the ruling government of the country from which he claims to be a refugee considers his conduct to have been styled as political activity." 305

In a number of States Parties to the UN Refugee Convention, courts have held that, in terms of Article 1.F of the Convention, an applicant who has committed a politically motivated crime in his or her own country of origin is not entitled to refugee status where the crime was a war crime, a crime against humanity, or an act of terrorism. ${ }^{306}$ This issue was addressed in the South African case Tshiyombo $v$. Members of the Refugee Appeal Board. ${ }^{307}$ In this case, applicant Kenneth Tshiyombo claimed that he had been kidnapped and forced to join a rebellion against the government of the Democratic Republic of the Congo in the Eastern part of the country. Although he had no "actual" alliance to the rebel group-his membership having been coerced-he feared persecution on account of his "perceived association" with it. The Court found "it did not matter for the purpose of his asylum application that the applicant did not share the political opinions of the

him because of that political opinion, rather than because of his refusal to fight with them.").

303. See Sangha v. INS, 103 F.3d 1482, 1488-89 (9th Cir. 1997); Ravindran v. INS, 976 F.2d 754, 760 (1st Cir. 1992); Rajaratnam v. Moyer, 832 F. Supp. 1219 (N.D. III 1993). See also T. ALEXANDER ALEINIKOFF, IMMIGRATION AND CITIZENSHIP PROCESS AND POLICY 1095 (4th ed. 1998); Shayna S. Cook, Repairing the Legacy of INS v. Elias-Zacarias, $23 \mathrm{MICH}$. J. INT'L L. 223 (2002).

304. Imputed political opinion has been accepted in Canadian jurisprudence in a string of Federal Court of Appeal decisions, including: Hilo v. M.E.I., [1991] 130 N.R. 236 (Can.); Amayo v. M.E.I., [1982] 1 F.C. 250 (Can.); Jerez-Spring v. M.E.I., [1981] 2 F.C. 527 (Can.); Gonzalez v. M.E.I., [1981] 2 F.C. 781 (Can.); Astudillo v. M.E.I., [1979] 31 N.R. 121 (Can.). 305. Ricardo Andizes Inzunza Orellana v. M.E.I., [1979] 103 DLR (3d) 105 (Can.).

306. INS v. Aquirre-Aguirre, 119 S. Ct. 1439 (1999); T. v. Immigration Officer [1996] UKHL 8 (HL); Suresh v. Canada (Minister of Citizenship and Immigration), [2002] 1 S.C.R. 3 (Can.). See generally P.J. VAN KRIEKEN, REFUGEE LAW IN CONTEXT: THE EXCLUSION CLAUSE (1999) (describing when an individual is not entitled to refugee status).

307. Tshiyombo v. Members of the Refugee Appeal Bd. 2016 (4) SA 469 (WCC) at para. 29 (S. Afr.). 
rebel group or had not voluntarily been a member of it." 308 The Court noted that the Refugee Appeal Board had concluded that the applicant was not entitled to refugee status without any reference to section 4 of the Refugees Act and had, by mere inference and without concrete evidence, rejected his claim to have a well-founded fear of persecution because "he had been a willing member of the rebel group and had probably participated in gross human rights violations." 309 The Court rejected the Board's reasoning and set aside its decision to reject the applicant's appeal against the rejection of his application by the RSDO. 310

More recently, the Constitutional Court of South Africa considered the question of a political crime for purposes of exclusion from refugee status in Gavrić v. Refugee Status Determination Officer, whose facts were discussed earlier. ${ }^{311}$ The decision is particularly important here for its authoritative analyses of the nature of a political crime and the principle of non-refoulement.

The Constitutional Court dealt in some depth with the nature of a political crime for purposes of the exclusion clause under section 4(1)(b) of the Refugees Act. The Court stated that "egregious acts of violence, such as acts commonly considered to be of a 'terrorist' nature that are wholly disproportionate to any political objective, will be unlikely to pass the test for political crimes." 312 However, the Court also expressed "the concern that one nation's terrorist may be another's freedom fighter ... [and that] this is particularly true where an organization advances the values of human rights, freedom and tolerance against a despotic or intolerant government ... [and concluded] that a content-neutral test is helpful in outlining relevant factors, but fails to take these important contextual considerations into account." 313 The court also concluded that "the approach to establishing whether a crime is political should be flexible, not overly inclusive or exclusive, and should also take into account our own historical context." 314 The Court was referring to the context in which South African courts during the apartheid era were

\footnotetext{
308. Id.

309. Id. ๆ 31.

310. Id. ๆ 47.

311. See Gavrić v. Refugee Status Determination Officer, Cape Town 2018 (38) ZACC 1 (CC) (S. Afr.).

312. Id. If 94 (the Court invoking the "predominance test" stipulated in UNHCR's Guidelines on International Protection: Application of Exclusion Clauses, Guideline No. 5, para. 15, and stating that according to this test, where there is no clear link between the crime and its alleged political motive, non-political motives are deemed predominant, and that such non-political motives may include personal reasons or gain).
}

313. Id. ๆ 105.

314. Id. ๆ 106. 
almost always inclined, if not politically expected, to dismiss alleged political crimes as terrorist acts.

While Gavric was successful in challenging the RSDO's decision on the basis of procedural unfairness, ${ }^{315}$ the Court found that he did not meet the requirements for refugee status according to the Refugees Act. In addition, the Court recognized the imperative behind the principle of non-refoulement. It took that view that while Gavric had not committed a political crime for which he would be persecuted should he be extradited to Serbia, he was nevertheless entitled to have his application considered fairly in accordance with the prevailing procedures., even if it was the Court's view that he did not satisfy the substantive criteria for the recognition of refugee status.

The Gavric judgment speaks to the duty of South Africa to abide by its obligations under the UN Refugee Convention and the OAU Refugee Convention, as well as customary international law obligations, and simultaneously to protect the rights of those who, by whatever unfortunate circumstances, find themselves seeking refuge within its borders.

\section{Membership of a Particular Social Group}

The UNHCR recognizes that "[m]embership of a particular social group may be at the root of persecution because there is no confidence in the group's loyalty to the [g]overnment or because of the political outlook, antecedents or economic activity of its [government's policies]." 316 It has been suggested that "membership of a particular social group" as a ground for persecution justifying a claim for refugee status is "the ground with the least clarity." 317 It is also a category that has, in recent years, received growing attention, as the number of refugee claims based on it has increased dramatically. ${ }^{318}$

A test for this category was developed in the seminal case of Ward $v$. Canada (Attorney-General). ${ }^{319}$ In that case, "a particular social group"

315. Id. ๆף 78-81.

316. UNHCR HANDBOOK, supra note 46, at para. 78.

317. See generally MICHELle FOSTER, THE 'GROUND WTTH THE LEAST ClaRITY': A COMPARATIVE STUDY OF JURISPRUDENTIAL DEVELOPMENTS RELATING TO MEMBERSHIP OF A PARTICULAR SOCIAL GROUP', UNHCR, LEGAL AND PROTECTION POLICY RESEARCH SERIES No. 25 (2012), http://www.unhcr.org/protect. See also James C. Hathaway \& Michelle Foster, Membership of a Particular Social Group, 15 INT'L J. REFUGEe L. 477, 477 ๆ 1 (2003).

318. T. Alexander Aleinikoff, Protected Characteristics and Social Perceptions: An Analysis of the Meaning of Membership of a Particular Social Group', UNHCR GLOBAL CONSULTATIONS ON INT'L PROTECTION 263, 264 (2003).

319. [1993] 2 S.C.R. 689, 737 (Can.). 
was defined as: “(i) groups defined by an innate or unchangeable characteristic; (ii) groups defined by a characteristic that is fundamental to human dignity such that a person should not be forced to relinquish it; and (iii) groups defined by a former status, unalterable due to its historical permanence." ${ }^{220}$ This definition was accepted in South Africa by the High Court (North Gauteng Division) in Fang $v$. Refugee Appeal Board. ${ }^{321}$ However, in the more recent case of Tshiyombo v. Members of the Refugee Appeal Board, the High Court (Western Cape Division) ventured its own definition of the term "particular social group," finding that it "denote[s] a section of society that is identifiable by the common characteristics of the persons comprising it or of the basis for their mutual coherence." 322 These decisions were, of course, predicated on the Refugees Act. The South African legislation is unique in the sense that it provides some guidance on the content of the term "social group." Section 1(xxi) of the Refugees Act states that the term "social group" includes, among others, "a group of persons of particular gender, sexual orientation, disability, class or caste."

The case law in South Africa, as in the United Kingdom and the US, is rich with concrete examples of the manifestation of "particular social groups." One category that emerges from these cases is women at risk of female genital mutilation (FGM). In $R \quad v$. Immigration Appeal Tribunal, ${ }^{323}$ the House of Lords was called upon to decide whether women in Pakistan constituted a particular social group. Lord Steyn stated that a premise of the UN Refugee Convention was that all human beings shall enjoy fundamental rights and freedoms, and that counteracting discrimination was a fundamental purpose of the Convention. ${ }^{324}$ Lord Hoffman rejected the notion that the term "particular social group" implies an element of cohesiveness, cooperation, or interdependence, and accepted that "social group" could include individuals fearing persecution on "such basis as gender, linguistic background and sexual orientation." 325 In another case ${ }^{326}$ the House of Lords held that a woman from Iran who was victimized because of her husband's political activities had a well-founded fear of

320. FosTER, supra note 317 , at 7.

321. 2007 (2) SA 432 (T) (S. Afr.) (the judge stating: "I associate myself with the categories of particular social groups as enumerated in the Canadian case of Ward.").

322. Tshiyombo v. Members of the Refugee Appeal Bd. 2016 (4) SA 469 (WCC) at para. 29 (S. Afr.).

323. [1999] 2 All ER 545 (HL).

324. Id. at 551 .

325. Id. at 563 .

326. See Sec'y of State for the Home Dep't v. K; Fornah v. Sec'y of State for the Home Dep't, [2006] UKHL 46. 
persecution by virtue of her membership of a particular social group, that is, her husband's family. In another case, the court held that a young woman from Sierra Leone, who feared that if she returned to Sierra Leone she would be at risk of FGM, had a well-founded fear of persecution because she belonged to a particular social group, namely the group of prospectively adult women in Sierra Leone who had not yet undergone FGM. Similarly, in In re: Kasinga, ${ }^{327}$ the US Board of Immigration Appeals considered the asylum claim of a nineteen-yearold Togolese woman on the basis that as a member of a social groupthe particular tribe to which she belonged-she would be forced to undergo FGM. The Board found that the particular social group of young women in her tribe who had not undergone FGM as practiced by that tribe, and who opposed the practice, fit the definition of members of a particular social group. ${ }^{328}$ The US Court of Appeals for the Second Circuit confirmed this decision in Abankwah v. INS. ${ }^{329}$

In South Africa, in Fang v. Refugee Appeal Board, ${ }^{330}$ the High Court rejected the notion that because he had more than one child, Mr. Fang was a member of a particular social group and that if returned to the People's Republic of China, he would fall foul of that country's one-childper-family policy. However, in Jacob van Garderen NO $v$. The Refugee Appeal Board, ${ }^{331}$ the High Court held that three young girls from the Democratic Republic of the Congo faced a real risk of persecution on account of their membership of a social group, namely, that of female children. The Court set aside the RSDO's decision to deny refugee status to the applicants and ruled that they were entitled to refugee status as members of a group that might be persecuted by armed groups.

327. In re Kasinga, 35 I.L.M. 1145 (1996).

328. See Abankwah v. INS, 185 F.3d 18, 25 (2d Cir. 1999) (noting the "BIA did not dispute that Abankwah's fear of genital mutilation was on account of her membership in a cognizable social group."); cf. Sanchez-Trujillo v. INS, 801 F.2d 1571 (9th Cir. 1986) (noting a "class of young, working class, urban males of military age does not exemplify the type of 'social group' for which the immigration laws provide protection from persecution."). See generally Arthur C. Helton, Persecution on Account of Membership in a Social Group as a Basis for Refugee Status, 15 ColUM. HUM. RTS. L. REV. 39 (1983) (examining the development of the "social group" category within its domestic and international background).

329. Abankwah v. INS, 38 I.L.M. 1267 (2d Cir. 1999) ("the decision of the BIA that Abankwah is not eligible for asylum is reversed").

330. Fang v. Refugee Appeal Bd. 2007 (2) SA 447 (T) at 454 B (S. Afr.) ("[T]hose resisting a valid State policy such as population control do not qualify as refugees.").

331. See South African Judicial Decisions, 33 S. AFR. Y.B. INT'L L. 511, 520 (2006). 


\section{CONCLUSION}

South Africa has been a major refugee receiving country since the end of apartheid. Although the numbers of asylum seekers have declined significantly from the high levels of a decade ago, there can be no doubt that the refugee issue still remains significant for South Africa domestically and internationally. Domestically, since 1994, the problem of refugees and asylum seekers in South Africa has often been conflated with that of illegal or undocumented migrants. The inauguration of the new post-apartheid government was almost immediately followed by alarmist accounts of unprecedented numbers of foreigners from other African countries descending upon South Africa's borders. These accounts also pointed at the emerging xenophobia, which was directed equally at refugees and illegal migrants. ${ }^{332}$ The phenomenon of xenophobia, with occasional outbreaks of public violence especially directed at persons from other African countries, reached its apogee in May 2008 and has continued to the present day. ${ }^{333}$ The most recent upsurge in violence against migrants occurred in the first week of September 2019, mainly in the cities of Johannesburg and Pretoria in Gauteng Province: the country's economic heartland. As on previous occasions, these attacks were directed exclusively at Africans-hence dubbed "Afrophobic" by some commentators and government officials ${ }^{334}$-and resulted in the deaths of at least twelve people

332. See, e.g., Kevin Tessier, The Challenge of Immigration Policy in the New South Africa, 3 IND. J. GLOBAL LEGAL STUD. 255 (1995); Judith Matloff, Flood of Ilegals Stymie a New South Africa, CHRIST. SCI. MONIT. (Jan. 5, 1995), at 5, https://www.csmonitor .com/1995/0105/05071.html; Liz Sly, South Africa is the New Lure for Continent's Refugees, CHIC. TRIB. (Oct. 9, 1994), https://www.chicago tribune.com/news/ct-xpm-1994-10-099410090444-story.html.

333. See generally Jonathan Crush, The Dark Side of Democracy: Migration, Xenophobia and Human Rights in South Africa, 38 INT'L MIGRATION 103 (2001) (documenting reports of citizen intolerance of non-citizens through surveys by the Southern African Migration Project); Anuoluwapo Durokifa \& Edwin O. Ijeoma, The Post-Apartheid Xenophobic Attacks in South Africa: A Reflection on Government Interferences, 31 AFR. POPULATION STUD. 3293 (2017) (asserting "that combatting xenophobic violence is more than merely altering or implementing a policy but requires addressing the fundamental basis that triggers conflict on which citizens lay their claim."); Braam Hanekom \& Leigh Ann Webster, The Role of South Africa's Government in the Xenophobic Violence of May 2008, 13 U. PENN. J. L. \& SOC. CHANGE 91 (2009-10) (exploring "the systems, conditions, and environment that gave rise to the infamous xenophobic violence that occurred in South Africa in May 2008"); Martin J. Murray, Alien Strangers in Our Midst: The Dreaded Foreign Invasion and Fortress South Africa, 37 CAN. J. AFR. STUD. 440 (2003) (using a "montage of anti-immigrant violence"); see generally Tella, supra note 7.

334. Notably, Naledi Pandor, South Africa's Minister for International Relations, purposefully used this term in her interview with Stephen Sackur on the BBC's HardTalk program that aired on Sep. 20, 2019. See South Africa's Naledi Pandor on 'Afrophobia', 
including both foreign nationals and South Africans. According to the UNHCR, "at least 1,500 foreign nationals, predominantly migrants but also refugees and asylum seekers, have been forced to flee their homes." ${ }^{335}$ Hundreds of people, mostly from Nigeria, but also from Malawi, Mozambique, and Zimbabwe, sought to return to their home countries for safety. Xenophobia in South Africa thus continues to be an issue that occasionally permeates South African domestic politics and sub-regional relations, not only with neighboring countries but also other countries farther afield, such as Ghana and Nigeria. ${ }^{336}$

The conflation of refugee and migration issues was compounded by the fact that until the Refugees Act came into operation on April 1, 2000 , administrators dealt with asylum applications under the Aliens Control Act, which made no provision for refugees. Thus, South Africa's policy toward non-nationals, including asylum seekers, reflected the sentiment that immigrants' and asylum seekers' rights should be as limited as possible. In practice, there was little understanding of the difference between asylum seekers and other immigrants, with the consequence that South African government authorities did not differentiate between types of non-nationals when determining the rights and services that non-nationals were entitled to. As is evident from the cases in which asylum seekers have appealed adverse decisions, some RSDOs and other decision-makers seemingly continue to lack a basic understanding of the scope and implications of the expanded refugee definition under Article I. paragraph 2 of the OAU Refugee Convention and the protection that asylum seekers are entitled to. Moreover, they do not always seem to appreciate fully the problems that individuals entering South Africa from refugee-producing countries, such as Burundi, Democratic Republic of the Congo, Eritrea, Ethiopia, Somalia, and Zimbabwe face, nor do they show any empathy even when presented with the relevant information. While the ratification of the UN Refugee Convention and the OAU Refugee Convention and their subsequent domestication represented significant developments for the protection of refugees and asylum seekers in South Africa, practice has not always matched legal principle. Officials

BBC NEWS (Sep. 18, 2019), https J/www.bbc.com/news/av/world-africa-49746180/southafrica-s-naledi-pandor-on-afrophobia.

335. See Charlie Yaxldy, Amid Rising Xenophobic Attacks in South Africa, UNHCR Ramps Up Aid for Refugees, Calls for Urgent Action, UNHCR (Sep. 20, 2019), https://www.unhcr.org/en-us/news/briefing/2019/9/5d848f694/amid-rising-xenophobicattacks-south-africa-unher-ramps-aid-refugees-calls.html.

336. See generally Francis Nyamnjoh \& Patience Mususa, Migration and Xenophobia, in REgION-BUILDING IN SOUTHERN AFRICA: PROGREss, PROBLEMS aNd PROSPECTS 215-29 (Chris Saunders, Gwingayi A. Dzinesa \& Dawn Nagger eds., 2012) (discussing aspects of economic, political, and global integration). 
responsible for implementing the obligations codified in the two conventions and South Africa's own domestic law continue to misunderstand and misapply them in their refugee status determination procedures.

It is in this context that the work of judges in South Africa has been both salutary and necessary for the protection of the rights of refugees and asylum seekers. The judicial responses and interpretations in the cases discussed in this essay bear testimony to the old adage that while judges may not be comfortable making law through their decisions, they cannot escape the reality that they do shape and clarify society's understanding of the law. In the process, they aid and push intransigent governments to apply the law faithfully or initiate changes in policy if the law so demands. Twenty-five years have elapsed since South Africa acceded to the OAU Refugee Convention and the UN Refugee Convention. And it has been almost two decades since its key domestic legislation, the Refugees Act, became operative. However, South Africa is yet to demonstrate a clear appreciation of the scope of the rights and legal protections that international law and its domestic law extend to asylum seekers and refugees on its territory. In the absence of interpretative guidance on the OAU Refugee Convention's expanded refugee definition, and the paucity of refugee rights jurisprudence from other jurisdictions among other States Parties to the Convention, the South African judiciary has borne the responsibility of interpreting these provisions. The judiciary has also both enriched the growing jurisprudence around the OAU Refugee Convention and the UN Refugee Convention and aided their practical application in addressing the protection of refugees in South Africa. Better awareness of international and domestic refugee law among government officials, in particular the authorities responsible for processing asylum applications and refugee status determination, would contribute to narrowing the existing gaps between legal protection and practical protection. 
